
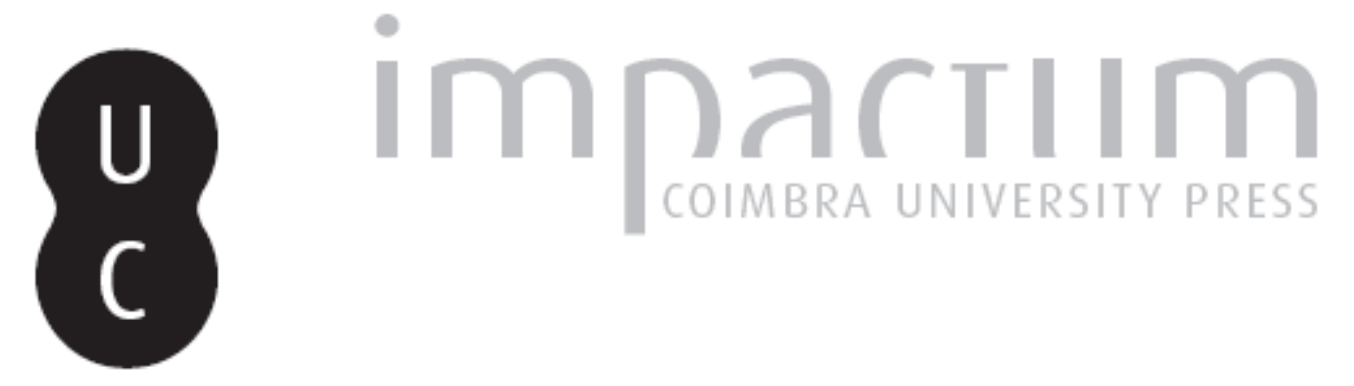

\title{
António Sérgio e os integralistas
}

Autor(es): $\quad$ Ferreira, Olga de Freitas da Cunha

Publicado por: Imprensa da Universidade de Coimbra

URL persistente:

URI:http://hdl.handle.net/10316.2/45052

DOI:

DOI:https://doi.org/10.14195/2183-8925_5-1_13

Accessed : $\quad$ 26-Apr-2023 14:33:34

A navegação consulta e descarregamento dos títulos inseridos nas Bibliotecas Digitais UC Digitalis, UC Pombalina e UC Impactum, pressupõem a aceitação plena e sem reservas dos Termos e Condições de Uso destas Bibliotecas Digitais, disponíveis em https://digitalis.uc.pt/pt-pt/termos.

Conforme exposto nos referidos Termos e Condições de Uso, o descarregamento de títulos de acesso restrito requer uma licença válida de autorização devendo o utilizador aceder ao(s) documento(s) a partir de um endereço de IP da instituição detentora da supramencionada licença.

Ao utilizador é apenas permitido o descarregamento para uso pessoal, pelo que o emprego do(s) título(s) descarregado(s) para outro fim, designadamente comercial, carece de autorização do respetivo autor ou editor da obra.

Na medida em que todas as obras da UC Digitalis se encontram protegidas pelo Código do Direito de Autor e Direitos Conexos e demais legislação aplicável, toda a cópia, parcial ou total, deste documento, nos casos em que é legalmente admitida, deverá conter ou fazer-se acompanhar por este aviso.

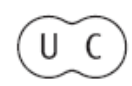




\section{REVISTA DE HISTÓRIA DAS IDEIAS 5}

\section{António Sérgio}

*

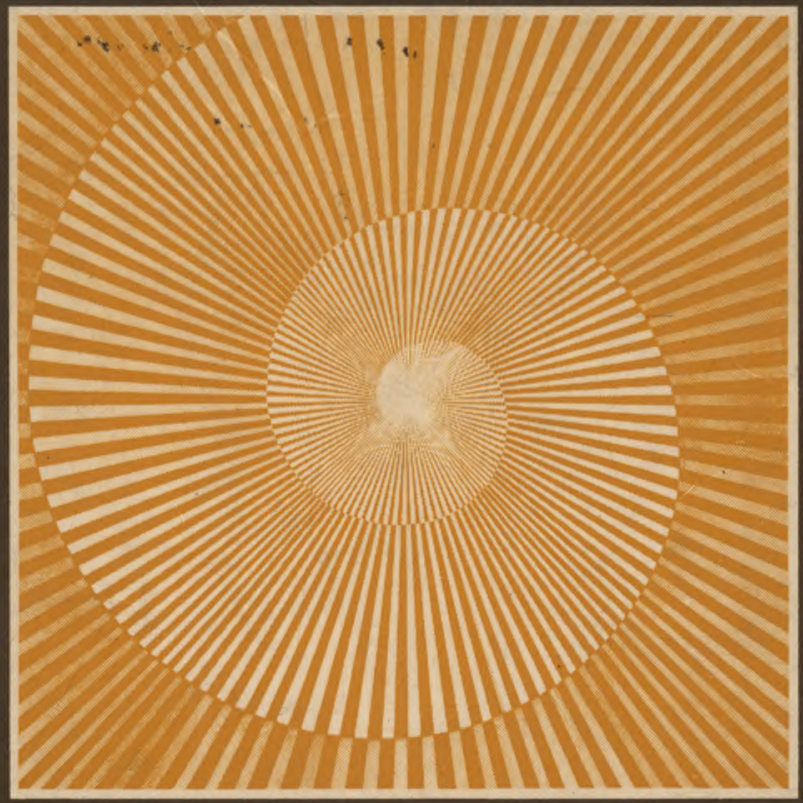

INSTITUTO DE HISTÓRIA E TEORIA DAS IDEIAS FACULDADE DE LETRAS 


\section{ANTÓNIO SÉRGIO E OS INTEGRALISTAS}

\section{DUAS PROPOSTAS DE RESSURGIMENTO NACIONAL}

A 5 de Outubro de 1910 surge finalmente a República. Com ela a expectativa de um ressurgimento nacional que traria a riqueza e a igualdade para todos. Enquanto muitos se faziam arautos de promessas, as inteligências iam sendo modeladas num clima de ideias e de retórica inflamada.

E neste ambiente de esperança que se constitui um movimento intelectual de feição nacionalista com sede no Porto, mas alargado a Coimbra e a Lisboa, denominado Renascença Portuguesa. A revista A Águia surgida em 1910 tornar-se-ia o núcleo gerador do movimento. Os intelectuais que agregava, apesar da heterogeneidade de ideário, eram animados pelo sentido da necessidade de um ressurgir da pátria, de dar uma finalidade à vida nacional através de uma via republicana, uma vez que a monarquia estava desacreditada. Esta sociedade eclética, que seria o cordão axial do movimento intelectual português durante a $1{ }^{\mathrm{a}}$ República, incubava desde o início o germe das polémicas e divisões que cedo se manifestaram O).

Se de início existiu uma certa coexistência entre os seus membros, as divergências não tardaram a impelir o movimento por caminhos bem diferentes. Mas, se as vias não eram coincidentes, o mesmo não se dirá dos objectivos, pois todos procuravam, ou pela criação literária e artística ou pela in-

* Faculdade de Letras da Universidade de Coimbra.

(D Ver Victor de Sá, Esboço histórico das ciências sociais em Portugal, Lisboa, Biblioteca Breve, 1978.

Veja-se, capítulos dedicados à «Renascença Portuguesa» e a «António Sérgio» e Historiografia Sociológica de António Sérgio, Lisboa, Biblioteca Breve, 1979. 
vestigação científica e histórica, encontrar as raízes e condicionantes da nacionalidade para que Portugal se reencontrasse consigo próprio.

Uns, identificavam o renascimento pátrio com um sentimento de saudade alicerçado no desejo de um retorno ao passado heroico e lendário. É o caso de Teixeira de Pascoais, mentor do movimento a partir de 1912, que colocaria na Saudade, "suprema criação sentimental da Raça», o princípio salvador da nacionalidade. Outros, de espírito mais realista e filiados ideologicamente em correntes de pendor racionalista, recusavam soluções teóricas e verbalistas, presas a princípios de ordem transcendente ou metafísica. A solução para os destinos da Grei devia encontrar-se numa via imanente, na resolução dos problemas reais e concretos.

O momento era único, como afirmava Raul Proença, mas devia ser aproveitado com a criação de uma dinâmica funcional que permitisse que das hostes republicanas saíssem as soluções para os problemas pedagógicos, sociais e económicos de que o país enfermava, e que constituíssem alternativa válida às soluções preconizadas pelas correntes saudosistas e tradicionalistas.

Situa-se neste campo António Sérgio que, denunciando as falhas do movimento da Renascença Portuguesa nas polémicas que manteve com Teixeira de Pascoais em páginas de A Águia, afirma a necessidade da criação em Portugal de uma «opinião pública esclarecida», de uma «elite consciente», em suma, de uma transformação da mentalidade. Com esse objeetivo lança a revista Pela Grei e liga-se à Seara Nova.

A «inteligência» portuguesa polarizava-se em duas orientações antitéticas, uma de natureza tradicionalista voltada para o passado, outra de natureza racionalista projectada no futuro, sem que o espírito nacionalista deixasse de subsistir e de se manifestar em ambas $\left({ }^{2}\right)$.

Mas se entre os tradicionalistas se integravam os que acreditavam nos caminhos da República como via segura para a resolução dos problemas da Nação, outros, descrentes da solução republicana e do liberalismo monárquico, impulsionam um movimento doutrinário e político com vista à restauração de uma monarquia orgânica, tradicionalista e anti-

(2) Idem, ibidem, p 96. 
-parlamentar $\left({ }^{3}\right)$. É o Integralismo Lusitano. Acusado de ser uma transplantação para Portugal do seu congénere francês, «L'Action Française», e do pensamento de Charles Maurras, cujas obras entraram em Portugal por intermédio de Luís de Almeida Braga, Pequito Rebelo e Conde de Monsaraz e causaram viva impressão em António Sardinha, defendia-se o Integralismo destas acusações, reivindicando raizes nacionais e originalidade própria para o movimento, que se pretendia herdeiro da tradição legitimista portuguesa $\left({ }^{4}\right)$. É em «chão português», ou seja, na tradição cultural e política do pensamento contra-revolucionário português do século XIX, cujos principais representantes os excessos da vitória liberal remeteram para o esquecimento, que o Integralismo se filia $\left(^{5}\right)$. Por outro lado, a recuperação que os representantes do movimento fazem, para além de Garrett e Herculano, de algumas das mais notáveis figuras da geração de 70, como Oliveira Martins, Teófilo Braga, Antero de Quental e Ramalho Ortigão, revela a preocupação de demonstrar que o seu ideário não se desvia da senda de um pensamento genuinamente português, sem qualquer servilismo ou enfeudamento a ideólogos estrangeiros $\left(^{\circ}\right)$. Silenciando as divergências profundas de pensamento e explorando os pontos de convergência possíveis, aqueles pensadores são arvorados em precursores ou mestres do pensamento integralista que neles fundamenta o seu anti-individualismo e consequentemente o anti-liberalis-

$\left.{ }^{3}\right) \quad$ Ver «O que nós queremos», Nação Portuguesa, n. ${ }^{\circ}$ I, Coimbra, 1914. Os Integralistas preconizam uma Monarquia orgânica tradicionalista $\mathrm{e}$ anti-parlamentar que assentaria $\mathrm{em} 2$ tendểncias: Concentradora (Nacionalista), que concede ao Rei, como Chefe do Estado, poder pessoal; Descentralizadora, que visaria os aspectos Económicos, Familiar e Administrativo, Judicial e Espiritual.

(4) Ver Manuel Braga da Cruz, «O integralismo lusitano nas origens do salazarismo», Análise Social, vol. XVIII, 1982-1. ${ }^{\circ}$ pp. 137-182.

$\left({ }^{5}\right)$ Entre os seus antecessores, os integralistas colocavam os principais representantes do pensamento contra-revolucionário do séc. XIX como Faustino da Madre de Deus, Gama e Castro, Penalva, José Agostinho de Macedo, Ribeiro Saraiva, França Galvão, Acúrsio das Neves e Fortunato de S. Boaventura.

(6) São inúmeros os artigos que atestam o modo como os integralistas fizeram uma leitura contra-revolucionária da vida mental do século XIX, o que os levou a pôr em destaque «o desengano de Garrett» a «desilusão de Herculano», «o pessimismo de Oliveira Martins», a "penitência de Ramalho», a «ironia de Eça», o "testemunho de Antero», a «contrição de Fialho». Teófilo Braga é considerado «Mestre da Contra-Revolução». Veja-se Manuel Braga da Cruz, ob. cit. 
mo económico e o anti-parlamentarismo, bem como a luta contra o egoísmo ético $\left.{ }^{7}\right)$.

O germe do movimento é lançado por um grupo de exilados na Bélgica, oriundos alguns deles dos meios académicos mais reaccionários da Universidade de Coimbra, logo após a implantação da República (Domingos de Gusmão Araújo, Luís de Almeida Braga e Rolão Preto). Ali fundam a revista Alma Portuguesa. Amantes da Tradição, acreditavam que só era possível corrigir os erros do presente com os modelos recuperados ao passado, sobretudo à Idade Média e Restauração.

Mas o Integralismo só surge verdadeiramente em 1914, com o aparecimento em Coimbra da revista A Nação Portuguesa, onde aparece o "programa integralista». Revelando uma maior homogeneidade de ideário que A Águia, A Nação Portuguesa insere nos primeiros números um conjunto de artigos que constituem as linhas mestras da doutrina que nos anos seguintes se vai desenvolver. E a partir de 1916, sobretudo com a vitória sidonista, que o movimento revela um maior pendor político, para o que contribui o lançamento do jornal A Monarquia. O fim do sonho sidonista e a instabilidade que se lhe seguiu levou o Integralismo a uma forte participação política que culminou com a revolta de Monsanto em 1919. Neste mesmo ano quebram a fidelidade a D. Manuel II e estabelecem contacto com o partido legitimista do ramo miguelista. Os fiéis a D. Manuel II (Alfredo Pimenta, Caetano Beirão e João Ameal), formam em 1921 a Acção Tradicionalista Portuguesa vindo a editar a revista Acção Realista e o semanário A Voz Nacional.

O período de intervenção política do Integralismo encerrar-se-ia em 1922 com a assinatura do Pacto de Paris entre D. Manuel II e a Infanta D. Maria Aldegundes de Bragança, tutora de D. Duarte Nuno. Neste mesmo ano reaparece a revista $A$ Nação Portuguesa sob a direcção de António Sardinha, e o movimento retoma a actividade doutrinária, na defesa do projecto de uma monarquia orgânica, nacional, tradicionalista. Não significa que o Integralismo tenha perdido influência. Esta vai-se alargando progressivamente a meios conservadores e a certos sectores estudantis, assumindo uma feição por um lado sindicalista e por outro nacionalista. Através desta segunda faceta aproxima-se dos movimentos fas-

O Ver Fernando Catroga, «O problema político em Antero de Quental - Um confronto com Oliveira Martins», Revista de História das Ideias, vol. III, Coimbra, 1981, p. 480 ss. 
cistas e nacionalistas europeus, vindo a influenciar o Estado Novo sobretudo em termos ideológicos $\left({ }^{8}\right)$.

A revista $A$ Nação Portuguesa, que como já afirmámos demonstra uma grande homogeneidade de ideário, fornece no percurso até 1926 os contornos exactos do pensamento integralista, tendo como grande teórico António Sardinha que o dota de um sistema doutrinário de certo modo coerente e radical. E se não quisermos ser injustos, temos que reconhecer que, enquanto liderado por António Sardinha, o Integralismo revelou certas posições de abertura, pese embora os ataques à «ideologia republicana». A comprová-lo está a revista Homens Livres que em 1923 reuniu integralistas e seareiros. No artigo "Almas Republicanas», designação que António Sérgio atribuiu aos melhores integralistas, António Sardinha não recusando o atributo mas precisando-lhe o sentido em termos de integralismo, afirma: «No restante, pelo que toca às partes e não ao todo, coincidimos sinceramente em solução com os 'democratas' que figuram nesta trincheira ombro a ombro connosco» $\left({ }^{9}\right)$.

Resumindo, a preocupação imediata de encontrar soluções para os problemas do presente é comum a Integralistas e Seareiros, de entre os quais destacamos António Sérgio, sobre quem de momento vai recair a nossa atenção pelas várias polémicas que manteve com alguns representantes do Integralismo. Com efeito, quer António Ségrio quer os Integralistas, apostavam no ressurgimento nacional. Se as soluções propostas são em muitos aspectos antitéticas, é no entanto pela análise histórica que um e outros pretendem encontrá-las. Só que, enquanto os Integralistas analisam a História com o objectivo de encontrar nela os modelos aos quais o presente deve regressar, António Sérgio faz essa análise para libertar o presente dessa mesma História. Daí que um confronto entre as duas concepções nos pareça indispensável para a compreensão das polémicas em que se envolveram os respectivos defensores, bem como das divergências que os separavam.

\section{EM TORNO DE DUAS LEITURAS DA HISTÓRIA}

Confrontados com duas leituras da História que nos pontos essenciais se opõem, poderá parecer ilógico procurar entre elas algum ou alguns pontos de convergência. Pensa-

$\left({ }^{8}\right)$ Manuel Braga da Cruz, ob. cit.

C) António Sardinha, "Almas Republicanas», Purgatório das Ideias, Lisboa, 1929, p. 284. 


\section{Antonio Sérgio}

mos, contudo, que é possível detectá-los, ainda que somente ao nível dos objectivos imediatos que presidiram àquelas leituras.

Quer António Sérgio quer os Integralistas procuravam encontrar soluções imediatas para a crise que afligia a sociedade do seu tempo, e um e outros viam na análise histórica a via de superação dessa crise. Por outro lado era convicção comum de que as razões últimas dessa crise assentavam numa profunda perturbação da mentalidade que urgia ultrapassar.

Para António Sérgio a mentalidade do seu tempo enfermava do vício do dogmatismo e de uma pseudocultura, a «sabença fictícia do pseudo culto», que só uma análise histórica poderia contrariar $\left({ }^{10}\right)$. Os Integralistas, com destaque para António Sardinha, identificavam a crise da mentalidade com a própria crise da Nacionalidade, resultante, por um lado, do desprestígio da Inteligência, e por outro, do abastardamento da Sensibilidade $\mathrm{O}^{1}$ ). Este abastardamento, iniciado na $\mathrm{Re}-$ nascença com a submissão a falsos modelos greco-romanos, prosseguiria noutros períodos do decurso da História portuguesa, com destaque para o Romantismo e para o Ultra-romantismo, representante da herança nefasta da Revolução Francesa. O desprestígio da Inteligểncia, não da Razão entenda-se, devia-se em grande parte às ideologias com que a Razão abastardava o pensamento, aliadas ao industrialismo moderno que influenciou negativamente a cultura pela sua apetência materialista. Nesta ordem de ideias, segundo António Sardinha, para superar a crise da Nacionalidade era imprescindível superar as da Sensibilidade e da Inteligência, o que quer dizer que era necessária uma renovação da mentalidade, ou seja, uma restauração cultural $\left({ }^{12}\right)$. Tudo isto pressupunha uma revisão da história de Portugal, corrompida, segundo os integalistas, pelo critério sectário do romantismo político. A revisão e a «crítica» da história anresentava-se como a única via que possibilitava o regresso de Portugal à plenitude do prestígio perdido.

Nesta linha de confronto, deparamos com uma certa sintonia de objectivos, traduzida numa preocupação comum pelos destinos da Grei. Só que deparamos também com um

( $\left.{ }^{10}\right)$ A análise histórica tem para Sérgio a finalidade de uma reforma da mentalidade. Não é a História que o interessa «mas somente a mentalidade com que nós a abordamos, por isso, tenho escrito sobre temas de História». Ensaios, t. IV, p. 211.

$\left.C^{11}\right)$ Ver António Sardinha, «Pratiquemos um reto de Inteligência», Purgatório das Ideias, Lisboa, 1929, pp. 143-180.

(12) Idem, ibidem. 
ponto que apenas na aparência é irrelevante mas que traduz uma diferença essencial entre as duas concepções de história. É que Sérgio, ao reflectir sobre «os vícios históricos», valoriza as razões económicas, pondo em prática uma concepção historiográfica de natureza não apenas histórica mas sociológica, resultante da necessidade de uma reflexão sobre as realidades sociais do passado e do presente com vista à construção do futuro. Aqui reside a grande novidade de Sérgio no campo da historiografia $\left({ }^{13}\right)$. Enquanto isto, os integralistas utilizam uma concepção apenas «histórica», em que, segundo António Sardinha, a história é vista como uma verificação e uma aplicação sociológica, na medida em que permite constatar as origens do abastardamento dos laços morais e sociais dos portugueses, causa profunda dos males presentes que é necessário debelar $\left({ }^{14}\right)$.

De qualquer modo julgamos estar em presença de duas concepções pragmáticas que dão à História um préstimo imediato, um fim útil, embora em Sérgio essa preocupação não desagúe no eruditismo, tão do agrado dos integralistas $\left({ }^{15}\right)$. Com efeito, não foi com espírito de historiador ou de «erudito» que António Sérgio se voltou para a história, como ele próprio o afirma no tomo IV dos Ensaios $\left({ }^{16}\right)$. A História é para ele uma pedagogia a ser divulgada $\left({ }^{17}\right)$. Nas Divagações Proemiais confessa essa intenção pedagógica que presidiu à elaboração da História de Portugal considerando-a, por isso, um ensaio histórico-social destinado a exorcizar a visão passadista da história portuguesa $\left({ }^{18}\right)$. Essa óptica interessa-lhe não apenas por exigências críticas e coerência intelectual, mas

$\left({ }^{13}\right)$ Para Sérgio, não é a História que influi no modo de viver do povo no presente, mas a atitude de espírito com que o povo considera a História, porque «quem vê com miragens o seu passado constrói com miragens o seu futuro». Ensaios, t. IV, p. 211.

ob. cit. $\mathbf{p}_{\mathbf{( 1 5}} 151$.

$\left({ }^{14}\right)$ António Sardinha, «Pratiquemos um acto de Inteligência»,

Ver António Sérgio, «Divagações Proemiais», Introdução Geográfico-Sociológico à História de Portugal, 3. ${ }^{\mathrm{a}}$ ed., Lisboa, Clássicos Sá da Costa, 1976, p. 2.

(16) Idem, Ensaios, t. IV, p. 211.

(") António Sardinha critica o utilitarismo cientifista que considera um dos males da Democracia, pois só faz a apologia dos bens materiais da vida. «Depois, pelo baixo critério utilitário que se apoderou da ciência com a sua pretendida vulgarização, que, no fundo se resume numa nova ordem de Industrialismo - no industrialismo da Inteligência». Ver «Pratiquemos um Acto de Inteligência», ob. cit. p. 148.

${ }^{18}$ ) António Sérgio, «Divagações Proemiais», ob. cit., p. 1. 
fundamentalmente devido aos efeitos sociais decorrentes da influência que sobre as pessoas exerce o modo como os acontecimentos históricos são inteligidos. É necessário, segundo o ensaísta, que as pessoas reconheçam que o passado não traz calor e que só devem recordá-lo para se libertarem do seu peso $\left({ }^{19}\right)$. A História é vista como um juiz do passado de que o homem se deve libertar, com o objectivo de realizar o futuro não como restauração, mas como inovação $\left({ }^{20}\right)$. Isto é, a «Nova Era» exige mudanças radicais, uma revolução integral que se não compadece com soluções «históricas», obsoletas, pelo que a História, longe de ser uma fonte de exemplos ou de «lições de moral», deveria ser um meio de familiarização com os problemas do presente $\left({ }^{21}\right)$.

Concepção oposta defendem os integralistas, para quem a História é uma fonte de experiência que fornece as normas do que foi para o que deve ser, e a possibilidade de renunciar ao que o presente tem de nocivo, trazendo do passado os elementos orgânicos que as miragens revolucionárias fizeram esquecer. O Passado «é que ensina a conhecer o presente e a esclarecer o futuro» $\left({ }^{22}\right)$. Daqui, que o remédio dos males do presente esteja para os integralistas, ao contrário de Sérgio, em soluções «históricas» recuperadas à Idade Média e à Restauração.

Quer dizer, a preocupação do ensaísta é menos a de informar sobre História do que a de formar os espíritos, sobretudo dos jovens, para uma visão filosófico-sociológica dos factos «como preparação para a obra de elevação do Povo que lhe cumpre agora empreender» $\left({ }^{23}\right)$. Enquanto isso, a preocupação dos integralistas, que do mesmo modo depositam as suas esperanças na nova geração, geração de predestinados, é encontrar na História a ideia coordenadora (Tradição), através da qual a Nacionalidade pode regressar ao seu «meio natural», à sua «ideia directriz», simultaneamente monárquica e católica romana.

E indubitável que um sentimento nacionalista está bem patente nestas duas concepções de História, mas enquanto em António Sérgio ele se projecta para o futuro e recebe uma so-

$\left.{ }^{10}\right)$ António Sérgio, «O passado como passado não me traz calor. Só dele me recordo para me libertar do seu peso». Ensaios, t. II, p. 5.

$\left({ }^{20}\right)$ Idem, «Divagações Proemiais», ob. cit., p. 2.

(M) Idem, ibidem, p. 3.

$\left.{ }^{22}\right)$ Ver Luis de Almeida Braga, «Do Espírito da Democracia», Nação Portuguesa, N. ${ }^{\circ}$ 9, 1915, pp. 279-285.

$O$ António Sérgio, Ensaios, t. IV, p. 4. 
bredeterminação cosmopolita, para os integralistas o nacionalismo é completado pelo tradicionalismo.

Prosseguindo o confronto, torna-se evidente que estas duas posições patenteiam atitudes mentais opostas.

Em Sérgio constatamos que a sua análise histórica assenta numa profunda reflexão filosófica. $O$ seareiro revela-se um racionalista para quem a interpretação dos factos assenta na razão, entendida como capacidade autónoma e judicativa. A sua análise histórica faz uso de um criticismo que, se combate as posições dogmáticas, permite simultaneamente o estabelecimento de uma pedagogia racionalista. Nesse sentido enuncia os grandes problemas ou, se quisermos, problematiza os acontecimentos históricos mais marcantes, renunciando a soluções definitivas para permitir que os espíritos, uma vez suscitada a sua curiosidade, tenham ocasião de reflectir sobre eles, no sentido de superarem posições dogmáticas e assumirem atitudes críticas $\left({ }^{24}\right)$. Coloca metodologicamente tudo em debate, numa atitude cartesiana de dúvida, levando os espíritos a ultrapassar esse estado mediante clarificações, superando tudo o que provoque limitações, exclusivismos ou imobilismos. Manifesta-se assim claramente partidário das correntes racionalistas e progressistas do seu tempo.

Ao invés, os integralistas, evidenciam uma atitude anti-racionalista, que se traduz na oposição a essas mesmas correntes e na invalidação da ideia de «progresso» e seus fundamentos evolucionistas $\left({ }^{25}\right)$.

Com efeito, apoiando-se em René Quinton, cujas experiências na visão integralista desfundamentaram o mito do Progresso Indefinido, contestam a ideia de «Evolução» que, perdendo o seu sentido fantasista passou a designar uma aturada manobra de permanência.

«A vida é». E como é, procura conservar a sua constância original, dado que qualquer desiquilíbrio provoca desarranjos que levam ao aniquilamento $\left({ }^{26}\right)$. E nas próprias correntes evolucionistas que os integralistas vão encontrar o fundamento para a ideia de Tradição, o que permite afirmar que a ciência desempenhou papel de relevo como fundamentadora da sua filosofia política.

$\left.C^{1}\right)$ «....desejaria incitar os especialistas de História a que nos dessem compêndios essencialmente críticos - como afastados, a um tempo, da pura erudição e de preocupações dogmáticas, obras inspiradas por uma atitude de exame, de dúvida metódica, de investigação libérrima». António Sérgio, «Divagações Proemiais», ob. cit., p. 4.

$\left.C^{25}\right)$ António Sardinha, VaZor da Raça, Lisboa, 1915, p. 137.

( $\left.{ }^{\mathrm{M}}\right)$ Idem, ibidem. 
$\mathrm{Na}$ verdade, transposta para o campo social a doutrina biológica em que se baseiam, ao conceito de evolução opõem o de Tradição, que permite, segundo António Sardinha, repelir o «romance do devenir social» resultante dos exageros das teorias transformistas, de que se teria socorrido Rousseau para elaborar a sua utopia da «bondade natural», de que deriva o erro grosseiro da democracia $\left({ }^{27}\right)$. A Tradição, entendida não como um ponto inerte no passado, mas como uma linha ininterrupta que encadeia gerações, idades, acontecimentos e homens, explica a solidariedade dos vivos com os mortos de que falava Comte, ou a sua afirmação de que «os mortos comandam os vivos» $\left({ }^{28}\right)$. Nesta linha de pensamento, em que a Tradição é a permanência no desenvolvimento, a ideia de «Progresso», mesmo quando exerça excepcionalmente uma função subtractiva para depurar aquela de elementos atrofiadores ou inferiores, não pode deixar de a implicar.

Assim sendo, esta análise anti-racionalista da História, que procura verificar nela o «facto» da tradição permanentemente depositado na memória da nação, impossibilita a explicação de qualquer dinâmica transformadora na própria História, sem que as transformações operadas sejam consideradas espúreas, ou excrescências contrárias à natureza da nação porque a desviam da sua «ideia directriz» $\left({ }^{29}\right)$. Foi o que aconteceu com a Renascença, com a ideologia da Revolução Francesa e com a Revolução Liberal.

António Sardinha, pese embora as críticas pertinentes, concede à «Tradição» um carácter dinâmico e existencial e considera-a a chave mestra do seu pensamento «contra-revolucionário» e «católico-romano» $\left({ }^{\mathrm{so}}\right)$. Por esta via se manifesta também o anti-racionalismo do pensamento histórico-político integralista, estruturado, por um lado, em torno da filosofia positivista, por outro, em torno da influência neo-escolástica e, por outro ainda, em torno dos valores essenciais da contra-

\section{p. 154.}

$\left({ }^{27}\right)$ Idem, «Pratiquemos um Acto de Inteligência», ob. cit.,

(28) Idem, ibidem, p. 153.

(20) São muitos os escritos em que os integralistas se referem às «influências estranhas» $\mathrm{e}$ «desnacionalizadoras» que, violando as condições da existência colectiva, desviam a Nacionalidade do seu «meio vital». A título de exemplo citamos de António Sardinha, "O Integr alismo Lusitano», o Valor das Raças; "Pratiquemos um Acto de Inteligência», $\mathbf{O}$ Purgatório das Ideias; Xavier Cordeiro, «A Desnacionalização do nosso Direito», ${ }_{A}$ Nação Portuguesa, n. ${ }^{\circ}, \quad$ l. $^{\mathrm{a}}$ série, 1915. Lisboa, Edições Gama, 1940.

$\left.{ }^{(30}\right)$ Ver António Sardinha, Ao Princípio era o Verbo, 2. ${ }^{a}$ ed., 
-revolução, concebidos pelos integralistas na linha de pensamento de Gama e Castro, como imbuídos de uma «lógica natural e divina» inexistente nos valores racionais absolutizados pela Razão $\left(^{31}\right)$.

Ao positivismo vai a análise histórica integralista buscar o método que põe em prática. Por aqui, opõe-se a metodologia integralista à seguida por António Sérgio, na medida em que é pela observação e investigação dos factos que se vão tentar conhecer as leis a que a nação como corpo social está sujeita, e o modo como podem e devem ser aplicadas na organização de um país ${ }^{32}$ ). Neste contexto, a posição integralista é a da defesa da política do facto, no que denota profunda influência de Charles Maurras. «E o facto que nos inspira, unicamente o facto»» $\left.{ }^{33}\right)$, posição perfeitamente contraposta à de António Sérgio que defende uma concepção ética de compreensão da História.

Para o ensaísta, o importante na História não são propriamente os factos, o importante é a relação que a razão permite estabelecer entre eles. Daí que só seja possível compreender a história portuguesa desde que dela se tenha uma visão de unidade (a formação de Portugal e a expansão não são fenómenos distintos mas um só - a passagem da economia agrária local à economia burguesa, comercial e marítima, graças aos Descobrimentos) $\left.{ }^{34}\right)$. Assim, para o seareiro, a História não é uma ciência discursiva a que baste uma descrição dos factos assente numa ordem cronológica, como, pretendem os integralistas, fundamentados no positivismo. É necessário procurar o "fio invisível» que os une de modo a constituir com eles um todo coerente e sistemático.

António Sérgio não admite, à maneira positivista, o facto puro contraposto à «ideia» ou «teoria» como interpretação

${ }^{31}$ Sobre os vectores de formação do pensamento contra-revolucionário português, em que se integra Gama e Castro, ver de Luís Reis Torgal, Tradicionalismo e Contra-Revolução. O Pensamento e a acção de José da Gama e Castro, Coimbra, 1973.

$\left({ }^{32}\right)$ Ver Luís de Almeida Braga, art. cit.

(33) António Sardinha, O Valor da Raça, p. 152.

$\left({ }^{34}\right)$ «Com isto obtém-se, ao mesmíssimo tempo, a visão da unidade do nosso objecto: e assim a formação e a expansão da nação portuguesa não nos aparece já como dois fenómenos, mas como um único: e este é um aspecto - da passagem da economia agrícola e local da primeira parte da Idade Média para a economia burguesa, comercial, marítima (e de mercado universal) que chegou à plenitude nos tempos actuais, graças à obra que nos caracteriza a nós, Portugueses, como um povo realmente histórico: os Descobrimentos» (António Sérgio, «Duas palavras de Advertência», Breve Interpretação da História de Portugal, Lisboa, Clássicos Sá da Costa, 1976, p. 3). 


\section{Antonio Sérgio}

mental do mesmo facto. Este é concebido pelo ensaísta como uma construção mental, intimamente ligado ao todo e estabelecendo um conjunto de relações entendíveis com as circunstâncias que o envolvem $\left({ }^{35}\right)$. Daqui decorre que o critério de verificação do facto tal como Sérgio o apresenta, sempre como uma hipótese e nunca como um dado definitivo, só pode ser um critério provisório que reside no confronto da ideia a que preside a hipótese formulada ${ }^{36}$ ). Ao invés, para os integralistas, e ainda dentro da influência positivista, o critério de verificação só pode residir no testemunho do documento. E, segundo o seareiro, a posição do erudito não crítico que assume uma atitude ingénua de submissão à fé imposta pelo testemunho. Sem pretender competir com esses eruditos, Sérgio procura ultrapassar com o seu critério a pseudo-filosofia da vaguidade e das «miragens», o «carácter arquivístico» do nosso «senso histórico», atraindo o leitor à «problemática intelectual» $\left({ }^{37}\right)$. Mais do que a «certeza», interessa-lhe a actividade mental provocada no leitor pela introdução dos problemas; mais do que as conclusões, interessa-lhe a própria análise; mais do que o facto mudo, interessa-lhe a hipótese fecunda que pode ser contestada, corrigida ou reformulada.

Resumindo, enquanto para os integralistas defensores da história arquivística, a objectividade do facto é exterior ao intelecto. independente da ideia porque reside nos testemunhos, para Sérgio a realidade do facto repousa na «coerência» de um sistema de ideias que nos permite interpretar uma aparência dada. $\left({ }^{38}\right)$.

$\mathrm{Na}$ sequência do confronto de que nos temos vindo a ocupar, teremos de constatar que na política do facto, tal como os integralistas a admitem, assenta um dos fundamentos do seu reaccionarismo, ao interpretarem a tradição como um facto, como um dado definitivo sempre presente na essência da própria nação. Eles próprios se assumem como defensores do «reaccionarismo biológico» de um agregado que sofreu a violação das condições primordiais da sua existência, às quais é necessário regressar.

$\left({ }^{35}\right)$ Ver António Sérgio, «Prefáceo para uma nova edição», Introdução Geográfico-Sociológica à História de Portugal, Lisboa, Clássicos Sá da Costa, 1976, pp. 241-244.

${ }^{36}$ ) Idem, «Historicismo arquivístico, Miragem retórica, e Problemática intelectual», Seara Nova, XI n. 310, Lisboa 1936, pp. 339-345.

$\left(\begin{array}{l}\mathrm{3T} \\ )\end{array}\right)$ Idem, ibidem, p. 342.

( $\left.{ }^{38}\right)$ Idem, ibidem, p. 344. 


\section{Antonio Sérgio e os Integralistas}

Em contrapartida, António Sérgio, ao combater essa mesma política, se se afasta da concepção que intelege o facto explicado por outro numa obediência rigorosa ao princípio da causalidade, como se cada um constituísse por si um todo absoluto, demarca-se também da interpretação dado à sua obra à base do materialismo histórico.

Assumindo a posição de um idealista histórico, o ensaísta recusa aquela interpretação quando, por exemplo no Prefácio para uma Nova Edição, diz que se enganam os que pretendem ver na sua interpretação da história de Portugal a aplicação de uma epistemologia redutora em que «factores geográficos» ou «factores económicos» se impusesse como uma fórmula geral ou como um absoluto a tudo o resto $\left.{ }^{(39}\right)$. Não podemos esquecer que para o ensaísta as causas dos acontecimentos históricos são ideias (criações do espírito) que os homens têm dos factos.

Não significa que criar a ideia, seja realizá-la, na medida em que existem condições circundantes que por vezes a desviam da linha pensada ou sugerem outro caminho. Mas uma coisa são circunstâncias, outra, factores que são sempre ideias. E se é certo que até hoje foi a ideia de riqueza a que mais impeliu o homem, essa ideia nada tem a ver com o materialismo histórico, para quem o económico tudo rege e para quem a sociedade coisificada sofre a influência de forças materiais que se exercem independentemente das ideias que os homens concebem da sociedade $\left({ }^{40}\right)$. Ao combater o materialismo histórico, Sérgio está a defender o seu idealismo que estende ao modo como concebe a própria sociedade.

As sociedades são entendidas como sistemas de relações pensadas de cada indivíduo com os seus semelhantes. Assim não são distintas nem superiores aos indivíduos, não são coisas mas ideias. Neste contexto, António Sérgio manifesta-se um individualista, e como tal um opositor à concepção organicista da sociedade tal como era defendido pelos integralistas. É que o organicismo invalidava as premissas em que assentava a concepção da democracia bem como o projecto

$\left({ }^{39}\right)$ Idem, «Prefáceo para uma nova edição», ob. cit., p. 243.

$\left(^{40}\right)$ Idem, ibidem, p. 244. Sobre a posição idealista de Sérgio ver de V. Magalhães-Vilhena, Em torno da génese do idealismo filosófico de Sérgio, in «Homenagem a António Sérgio», Lisboa, Academia das Ciências de Lisboa, 1976, pp. 123-45 e ainda António Sérgio. $O$ idealismo Crítico e a Crise da Ideologia Burguesa, Lisboa, Seara Nova, 1964. 
sergiano de uma república cooperativista construída à base do contrato livre entre as partes $\left({ }^{41}\right)$.

Os integralistas, ao defenderem uma concepção organicista da sociedade, faziam radicar a ordem política nos órgãos intermédios - Família, Corporação e Municípios. A base da sociedade é a família, a que o erro da revolução liberal sobrepôs o indivíduo. Deste anti-liberalismo resulta por sua vez o anti-parlamentarismo e a atitude anti-democrática da condenação da teoria do sufrágio que, segundo os integralistas, veio inverter a ordem da autoridade e contribuir para o espírito de rebeldia que leva sempre à anarquia $\left({ }^{42}\right)$. Este erro só poderia ser corrigido mediante um regresso ao tipo de representação em cortes, onde as classes sociais compareciam perante o soberano para defenderem os vários interesses.

Neste contexto, o projecto político imediato subjacente à análise histórica integralista consiste em restaurar Portugal pela Monarquia hereditária, orgânica, corporativa, segundo o espírito da monarquia medieval. E aqui bem patente a influência da filosofia neo-escolástica e através dela das correntes tomistas. Reflecte-se na oposição aos postulados racionalistas e contratualistas sobre a origem do poder e na aceitação da doutrina jusdivinista fundamentadora da monarquia assente no pactum subjectionis que o integralismo pretende restaurar $\left({ }^{43}\right)$.

Quer dizer, o projecto político integralista consiste, no fundo, em arvorar o tradicionalismo num restauracionismo, ou, por outras palavras, num retorno à monarquia tradicionalista apoiada num catolicismo integrista. Daqui resulta que o combate à República não se situa apenas no campo meramente político, mas no ideológico, pelo carácter ateu e materialista que o Integralismo the reconhece.

Não é de estranhar que ligado ao projecto político existisse um projecto pedagógico, revelador, por um lado, de uma grande influência da escolástica traduzida na defesa do ${ }^{1}$ restauro do ensino das «humanidades», e por outro, numa preocupação moralizante. Esse ensino deveria formar uma elite

$\left({ }^{41}\right) \quad$ Fernando Catroga, $o b$. cit., pp. 155-57. Ver a leitura que António Sérgio faz de Antero de Quental.

$\left.C^{2}\right)$ Hipólito Raposo, «Natureza da Representação», Nação Portuguesa, l. ${ }^{\text {a }}$ série, n. ${ }^{\circ}$ 5, Nov. de 1915.

$\mathbf{C}^{43}$ ) Ver António Sardinha, A Teoria das Cortes Gerais, 2. ${ }^{\mathrm{a}}$ ed., Lisboa, 1975. Sobretudo o Cap. VIII. 
disciplinada, temente a Deus, obediente às directrizes da Igreja Católica, Apostólica e Romana $\left({ }^{44}\right)$.

Em conclusão: a concepção histórica integralista, consagrando o positivismo de direita como base do seu discurso contra-revolucionário, manifestando uma atitude mental anti-racionalista e combatendo a teoria do «Progresso», arvora a «Tradição» na trave mestra do seu projecto de estabelecimento de uma ordem nova que se concretizaria com o regresso a um modelo inspirado na mitificação da Idade Média.

A concepção de António Sérgio, recusando fazer história romântica ou nacionalista com o intuito apologético de apresentar acontecimentos e personagens do passado como modelos a seguir no presente, entende a História como um instrumento de educação humanista libertadora de miragens e de espectros, obstáculos mentais à concretização do destino universalista português, prefigurado nos Descobrimentos, mas que urgia estender à esfera moral $\left({ }^{45}\right)$.

\section{TRÊS EXPLICAÇÕES PARA TRÊS POLÉMICAS}

Do confronto feito entre as leituras da História de António Sérgio e dos integralistas, é fácil inteligir as razões fundamentais que presidiram aos conflitos de ideias que opuseram o ensaísta a representantes do Integralismo ou a outros cujo pensamento não se afastava das traves mestras das doutrinas adoptadas pelo movimento. Contudo, não pode esquecer-se que nesses conflitos pesou sobremaneira o carácter polémico do pensamento sergiano que, pelas suas preocupações de problematização e intervenção, forçosamente acarretava oposições e resistências.

Como tivemos ocasião de constatar, o objectivo do ensaísta era fazer da História uma pedagogia racionalista que levasse os leitores a uma atitude de reflexão crítica e ao consequente abandono do dogmatismo puro. Não é de estranhar, portanto, que o espírito crítico e problematizador que preside à sua análise histórica, aliado a uma certa veia satírica que

$\left({ }^{44}\right)$ Estes tipo de ensino é frequentemente publicitado na revista $A$ Nação Portuguesa, conjuntamente com os colégios que o ministram. Seria interessante um estudo sobre estes estabelecimentos de ensino e sobre os programas que punham em execução. Por nossa parte procuraremos dar uma achega nesse sentido no estudo que preparamos sobre Cultura e Política nas concepç̃es do Integralismo Lusitano.

$\left({ }^{45}\right)$ António Sérgio, Breve Interpretação da História de Portugal, Lisboa, Clássicos Sá da Costa, 1975, p. 146. 
não raras vezes evidenciou - e se manifestou contra o academismo, o dogmatismo e o especialismo infecundo - concorra para os conflitos de ideias e para as polémicas em que se envolveu.

O próprio autor o admite ao considerar-se um excitador dos espíritos, que acaba sempre por ganhar as partidas, mesmo «que o sangrem» ou lhe «refutem vitoriosamente as obras» $\left({ }^{46}\right)$. É que o opositor, ao discutir as interpretações da História, faz precisamente aquilo que o crítico quer, segue o caminho do ensaísta - pondera, reflecte sobre os factos. Levado a debater ideias, a problematizar, a pensar hipóteses, encontra a possibilidade de despertar, como já Kant o havia afirmado, do seu «sono dogmático» $\left({ }^{47}\right)$.

Esta posição coloca porém um problema que merece ser considerado. Ao enunciar os factos como hipóteses susceptíveis de serem superadas ou corrigidas e não como dados definitivos ou verdades conclusas, Sérgio não esconde um certo dogmatismo, atitude que pretendia combater. Com efeito, ao colocar metodologicamente tudo em dúvida, com excepção do seu ponto de partida, o seareiro evidencia a preocupação de conduzir os espíritos à aceitação da sua própria verdade. $\mathrm{O}$ diálogo com o interlocutor desaparece porque, no fundo, não lhe interessa tanto a verdade dos outros mas que a sua verdade seja aceite. Não é de estranhar, portanto, que alguns desses interlocutores o acusem de orgulhoso, de auto-suficiente que se não limita a defender os seus pontos de vista, mas a fazer deles verdadeiros pontos de honra $\left({ }^{48}\right)$. É evidente que na linha da lógica do pensamento sergiano era impossível ser o autor a desviar-se, ou seja, a corrigir ou a reformular as hipóteses que havia proposto, sem que daí adviesse quebra da unidade de um pensamento que durante o seu percurso permaneceu sempre fiel a si próprio.

$\mathrm{O}$ ensaísta reconhece o facto e parece até pretender torná-lo evidente quando admite que as suas intuições as descobriu por si próprio, antes de ter lido os filósofos que lhas poderiam comprovar (Platão, Descartes, Espinosa, Kant, Fichte), bem como os escritores que o influenciaram na elaboração do seu programa pedagógico-social (Antero e Oliveira Martins). Esse «ó priori» na origem das suas intuições, permite supor que desses filósofos e escritores António Sérgio

$\left({ }^{46}\right)$ Idem, «Divagações Proemiais», ob. cit., p. 5.

$\left.{ }^{47}\right)$ Idem, ibidem.

$\left({ }^{48}\right)$ E o caso de Carlos Malheiro Dias, no Prefácio para a Nova Edição da Exortação à Mocidade, Lisboa, 1925, p. 10. 
tenha retirado apenas o que as corroborava. Assim a inalterabilidade do pensamento sergiano pode levar a concluir que as suas hipóteses só podem ser entendidas como verdades definitivas que os interlocutores não podem alterar, mas apenas confirmar $\left.{ }^{49}\right)$. É certo que Sérgio afirma que o seu mérito não está nas conclusões que propõe ou enuncia, mas na actividade intelectual efectiva que conseguir provocar nos leitores. Ora não são as conclusões de uma análise que provocam essa actividade, mas a própria análise. No entanto, o «démolissez moi» que ele propõe ao interlocutor, à semelhança de Claude Bernard, é quase ou mesmo impossível $\left({ }^{50}\right)$. Para isso, seria necessário que Sérgio aceitasse a verdade do opositor ou modificasse as suas próprias hipóteses, o que colocaria em perigo a unidade ou pelo menos o carácter de inalterabilidade do seu pensamento.

Estas considerações críticas ao criticismo sergiano não podem deixar de ser levadas em conta por quem se debruce sobre os conflitos de ideias em que Sérgio se envolveu. Se esses conflitos encontram sérias razões no carácter problematizador do pensamento do ensaísta, não é menos verdade que as encontram também no carácter interveniente desse mesmo pensamento. Concebendo a História como um meio de intervir na vida da nação, forçoso era que essa concepção lhe acarretasse fortes oposições e resistências, vindas, por um lado, dos representantes do romantismo nacionalista da geração de $90 \mathrm{e}$, por outro, dos cidadãos jacobinos, ou seja, do próprio sector republicano, que olhava Sérgio com desconfiança. Os primeiros, como diz o seareiro no Prefácio à $1 .^{\mathrm{a}}$ Edição dos Ensaios, criaram «um florido de mitos em que se dissolveu o espírito público, não só sobre os aspectos da nossa vida e sobre as realidades contemporâneas, mas até sobre o génio do Português e as altas façanhas da sua história» $\left({ }^{5}\right)$. Os segundos, tinha-os Sérgio «no conceito de conservadores ou retrógrados por descurarem os problemas de natureza económica» que o ensaísta sempre considerou basilares $\left({ }^{52}\right)$. Considerando como prioritárias as reformas de natureza económica, criticava os republicanos por não olharem de frente os verdadeiros problemas nacionais, convencidos de que bastava a laicização da sociedade, ou seja, a separação da Igreja do Estado para que todos os males fossem curados.

\footnotetext{
$\left({ }^{49}\right)$ Ver Fernando Catroga, ob. cit.

$\left.{ }^{50}\right)$ António Sérgio, «Historicismo arquivístico, Miragem retórica, e Problemática intelectual», ob. cit.

$\left.{ }^{51}\right)$ Idem, «Prefácio à.$^{\mathrm{a}}{ }^{\mathrm{E}}$ Ed.» Ensaios, t. I, p. 56.

$\left.{ }^{82}\right)$ Idem, «Prefácio à 2. ${ }^{\mathrm{a}}$ Ed.» Ensaios, t. I, p. 33.
} 


\section{Antonio Sérgio}

Foi toda esta conjuntura que, como afirma, o forçou a debruçar-se sobre os "vícios históricos» da sociedade portuguesa para encontrar as causas da decadência dos povos peninsulares, a opôr-se às resistências de românticos e jacobinos e a combater as miragens retóricas que poluíam a atmosfera mental em que se viu envolvido desde que saiu da adolescência $\left({ }^{53}\right)$. Assim se explicam as reacções contra as teses divergentes das suas, opondo-se aos seus autores não numa atitude de historiador contra historiądores mas numa atitude de pedagogista racional e crítico. E nessa qualidade que não pactua com os fantasmas do romantismo, com os mitos do sebastianismo e messianismo, «desvairos de mente nacionalista», «espectros» transmitidos pela tradição, que é necessário exercizar porque contrários à racionalidade.

É ainda como pedagogista que se opõe ao mito do «seiscentismo» em que assenta a exaltação de um período considerado paradigmático, ao qual, segundo os seus defensores, era urgente regressar. De modo nenhum esta solução para os males do presente se enquadrava na visão sergiana da história portuguesa, por demais racionalista para permitir arvorar em modelo um período acentuadamente irracional e decadente, sobretudo se confrontado com o período áureo do renascimento e dos descobrimentos, esse sim paradigmático na opinião do seareiro.

Esse regresso ao passado, essa «utopia regressiva», fruto da incapacidade de luta dos espíritos contra as miragens, os mitos e os espectros, numa clara submissão ao ser que a História lembra, está em completa contradição com as preocupações sergianas de construção de uma sociedade futura, fundada nos princípios da razão, entendida como capacidade de harmonia e coerência mental, como razão teórica, mas também como razão prática que, sobredeterminando a teoria, procura em nome de um ideal de Justiça opor ao ser da História um dever ser ditado pelas afirmações intrínsecas da consciência. Quer dizer, à «utopia regressiva», fruto da falta de senso crítico, opõe Sérgio uma «utopia prospectiva» fundada na razão. A nosso ver é essa a lição essencial a extrair das polémicas de que nos ocuparemos de seguida.

$\left({ }^{53}\right) \quad I d e m$, «História arquivística, Miragem retórica e Problemática intelectual», ob. cit. 
1-A «Exorcizâção dos Espectros» ou a «Questão do Desejado»» $\left({ }^{54}\right)$.

Na Exortação à Mocidwde, Carlos Malheiro Dias incita a nova geração a resgatar a Pátria, destruída pelo materialismo e pelo racionalismo que limitado ao objectivo não conta com os imponderáveis do sentimento. Fundamentando-se nas «lições da história», combate esse racionalismo, porque, criador do «mito da soberania das multidões» com o seu desvairo, dissolveu a própria consciência nacional, e combate o materialismo, destruidor da seiva do patriotismo, verdadeiro ideal dos sentimentos colectivos $\left({ }^{55}\right)$.

Opõe-se portanto às posições que defendem o nascimento das pátrias com base em sociedades preocupadas apenas na defesa dos interesses materiais, sustentando que estas se fizeram com mártires, poetas e heróis, e tiveram na sua origem as religiões. Portugal é disso exemplo flagrante, porque em grande parte é fruto da luta travada entre o ideal cristão e o islâmico, e os próprios descobrimentos não se podem desligar do anseio religioso da propagação da fé. A pátria por-

$\left.{ }^{(54}\right)$ Esta polémica, que opõe António Sérgio a Carlos Malheiro Dias, iniciou-se com a publicação da Exortação à Mocidade, texto de uma conferência que o segundo dos opositores deveria ter proferido na Universidade de Coimbra em Maio de 1924, a convite do Dr. Eugênio de Castro, então director da Faculdade de Letras daquela Universidade. A Conferência não chegou a realizar-se por ter sido impedida por sectores universitários, sobretudo estudantis, que contestavam a personalidade reaccionária de Carlos Malheiro Dias. António Sérgio publicou então uma colectânea de «testemunhos históricos» intitulada O Desejado, precedida de uma «Carta Prefácio a Carlos Malheiro Dias» em que contesta as teses defendidas por este na sua Exortação à Mocidade. $A$ revista $A$ Nação Portuguesa colocou as suas páginas à disposição do exortador para que pudesse responder a Ântónio Sérgio, mas a resposta surgiria num longo Prefácio que antecede uma nova edição da Exortação à Mocidade publicado em 1925. António Sérgio responde por sua vez com a Tréplica a Carlos Malheiro Dias sobre a questão de «O Desejado», numa ediçãa da Seara Nova, no mesmo ano. Não constituindo propriamente peça da polémica, é de assinalar a colectânea de documentos que António Sérgio elaborou sob a designação de Camões $e$ D. Sebastião em que pretende esclarecer dúvidas suscitadas pela publicação de $O$ Desejado, sobre o modo como a figura de D. Sebastião é tratado pelo poeta nos Lusíadas. Carlos Malheiro Dias, por sua vez, escreveu O Piedoso e o Desejado, obra de vulgarização em que continua a defender os seus pontos de vista. Sérgio refere-se-lhe dizendo que revela o mesmo espírito sebastianista da Exortação à Mocidade. Ver Tréplica a Carlos Malheiro Dias, Nota D, p. 81.

(55) Ver Carlos Malheiro Dias, Exortação à Mocidade, 2.a Edição, Lisboa, 1925, pp. 34-35. 
tuguesa é o resultado de um ideal espiritual, reflectido no esforço do povo luso chefiado por Afonso Henriques e, mais tarde, no esforço dos descobridores. Torna-se pois necessário exaltar o heroísmo e as nobres superioridades como base do nacionalismo, ou seja, o cultivo da defesa do espírito nacional contra influências estranhas que em vários períodos da história o vieram dissolver. Para Malheiro Dias é ponto assente que o materialismo aliado ao racionalismo constituem a causa primária dos males da pátria, contra a opinião dos que pretendem uma análise racionalista da sua história $\left({ }^{56}\right)$, numa clara alusão à posição defendida por António Sérgio.

Para o autor da Exortação, Portugal, no séc. XVI, saiu para fora da sua órbita numa preocupação imperialista de lusitanizar meio mundo. No séc. XIX foi, por sua vez, invadido pelo influxo desnacionalizador, deixando-se contaminar pelas doutrinas da Revolução Francesa que destruíram o equilíbrio das instituições tradicionais, dando clara preferência a uma liberdade estrangeira e recusando outra genuinamente portuguesa. Na perspectiva tradicionalista da História em que se coloca Malheiro Dias, só um regresso às concepções originárias do nacionalismo tradicional permitirão um ressurgimento da Grei que, contaminada pela incredulidade e pelos apetites materiais viu secar-se-lhe o duplo misticismo religioso e patriótico $\left({ }^{57}\right)$. A condenação que faz do "progresso violento» e das doutrinas que, desde 1820 , «desnaturaram o carácter nacional» é indicativo incontroverso do anti-racionalismo e do anti-progressismo da sua posição.

A «reconstrução» que preconiza, fundada nas «geniais condições da antiga integridade cívica e moral», deve fazer-se através de uma revisão da História, manancial de ensinamentos edificantes, mas desvirtuada pelos que, aplicando-lhe uma análise racional, suprimem dela o sentimento. E que a supressão do sentimento é, na opinião do exortador, caraeterística das concepções racionalistas e materialistas que não valorizam a acção de mártires e heróis, a exemplo de D. Sebastião, verdadeira reincarnação do Portugal do séc. XV, nem a compreensão de façanhas inspiradas no misticismo patriótico como foi a jornada de Alcácer Quibir.

António Sérgio, porque visado pelo autor da Exortação à Mocidade mas sobretudo por uma questão de coerência intelectual, na Carta Prefácio a Carlos Malheiro Dias, critica naquele a «romântica maneira de ver a história» que, tradu-

(") Idem, ibidem, p. 42.

$\left({ }^{67}\right)$ Idem, ibidem, p. 49. 
zida num anti-racionalismo e num anti-progressismo, culmina no culto do Desejado, ao mesmo tempo que se defende da acusação de filiar no materialismo histórico a sua interpretação da história portuguesa $\left({ }^{58}\right)$. $\mathrm{O}$ ensaísta não pode aceitar uma «posição demagógica» que defende romanticamente as suas doutrinas e que, atiçando o sentimento contra as razões, escolhe D. Sebastião como modelo de herói $\left.{ }^{59}\right)$. Seria pactuar com uma atitude irracional que não reconhece à razão, como capacidade judicativa, a possibilidade de conter as manifestações temperamentais e de justificar com razões os sentimentos. Não significa que Sérgio se oponha ao sentimento, só que permanecer nele, à semelhança dos apologistas do sebastianismo, seria para o seareiro revelar falta de senso crítico, característica da concepção romântica da História em que o opositor se filia. Ele próprio considera-se um temperamental e apaixonado, que, todavia, consegue submeter à ordem, à inteligência e à harmonia essas manifestações $\left({ }^{60}\right)$.

A condenação do mito sebástico é em António Sérgio fruto da posição de humanista crítico, preocupado com «o estilo de pensar e a disciplina de exame», que pretende preparar o futuro «exorcizando os espectros». Não é de modo algum uma posição filiada numa concepção materialista que, na opinião do seu opositor, o impedia de compreender a «mística patriótica» de D. Sebastião.

Não esqueçamos que a perspectiva sergiana de análise da história portuguesa não se coaduna com a tese céltica, segundo a qual os Descobrimentos explicam-se pelo sonho de encontrar as Ilhas Afortunadas e pelo ímpeto religioso. Rejeitando essa tese, Sérgio não encontra sensatez na pretensão da conquista de África por D. Sebastião e muito menos na sua manutenção se por ventura se concretizasse. Consequentemente, não aceita que a pretensão do Desejado fosse um reingresso na política nacionalista do «Império Africano», iniciada por D. João I, e animada pelo Infante D. Henrique, como preten-

\footnotetext{
$\left.{ }^{58}\right)$ Ver António Sérgio, «Carta Prefácio a Carlos Malheiro Dias», O Desejado, Lisboa, 1924, pp. 7-8.

( ${ }^{\text {C9 }) ~ « O r a ~ o ~ m e u ~ a m i g o, ~ s e ~ m e ~ d a ́ ~ l i c e n c ̧ a, ~ n a ̃ o ~ f o i ~ s o m e n t e ~ d e-~}$ magogo na casta do acto que praticou, - atiçando ali o sentido cego contra uma conclusão da inteligência, por ser clara $e$ intelectual: foi-o na escolha do seu falso herói; e foi-o, não menos, nas doutrinas politicas que defendeu». (António Sérgio, «Carta Prefácio a Carlos Malheiro Dias», ob. cit., p. 11).

$\left.{ }^{(60}\right)$ Idem, Tréplica a Carlos Malheiro Dias, Lisboa, Seara Nova, 1925.
} 
dia Malheiro Dias $\left({ }^{61}\right)$. Na opinião do autor de Exortação, essa política real e popular só não é compreendida pela «sebastofobia» de António Sérgio, devido ao racionalismo, que o impede de reconhecer em D. Sebastião o «ímpeto da luta, o ardor de ideal, a candura patriótica», virtudes que não toleram nem o materialismo cínico, nem o desalento céptico, nem o poderio do número perante o qual a razão renuncia $\left({ }^{62}\right)$. Por essas virtudes, pretende Malheiro Dias aproximar D. Sebastião dos heróis de quinhentos, sobretudo do Infante D. Henrique que, na sua fase de política africanista teria revelado o mesmo arrebatamento belicoso. Claro que esta posição vai ao invés da de Sérgio, para quem o Desejado era precisamente o oposto do herói quinhentista. Este, pela sua prudência, esclarecimento e racionalidade, contrastava com a imprudência, a impulsividade e a irracionalidade do vencido de Alcácer $\left({ }^{63}\right)$.

Sérgio rejeita portanto a interpretação não racionalista do sebastianismo, que os seus defensores levantam como bandeira da esperança nas horas de crise. O ensaísta entende-o como um narcótico, uma resistência ao progresso e à intervenção, fruto de uma posição romântica que, procurando o ideal na expansão do sentimento anárquico, faz a apologia das coisas gloriosas e não das racionais. Considerando que o mal reside fundamentalmente na falta de uma verdadeira cultura intelectual, Sérgio assume-se como pedagogista crítico e vinca a urgência de uma reforma da mentalidade, pois só ela permitirá o avanço da cultura. Este avanço reside, para Sérgio, na «limpeza e concertação da máquina cerebral e do modo de funcionamento do espírito» $\left({ }^{64}\right)$. Dessa limpeza e concertação resultará a tão necessária "exorcização dos espectros», entre os quais sobressai o "sebastianismo», símbolo no seu tempo da gangrena moral de que a nação padecia, espectro que ainda pesava, no entender do seareiro, sobre os que pretendiam resolver os problemas do presente com base nas mi-

( $\left.{ }^{\mathrm{C} 1}\right)$ Ver Carlos Malheiro Dias, «Prefácio para uma nova edição», Exortação à Mocidade, Lisboa, 1925 p. 12.

$\mathrm{O}^{52}$ ) Idem, ibidem, p. 27.

$O$ Ver António Sérgio, «Carta Prefácio a Carlos Malheiro Dias», ob. cit., p. 22.

(64) Idem, Tréplica a Carlos Malheiro Dias sobre a questão de «O Desejado». A mesma ideia defende A. Sérgio nas Divagações Proemiais: «eu cuido que avançar realmente em cultura consiste em renunciar àquele nosso hábito de confundir o acerto com o modernismo e de perfilhar as doutrinas como 'verdadeiros crentes'». «Divagações Proemiais», ob. cit., p. 8). 
ragens com que olhavam o passado $\left({ }^{65}\right)$. Convencido de que os sebastianistas, tal como os cépticos, só se curam com razões, resolveu António Sérgio agir pedagogicamente, colocando nas mãos dos leitores a documentação necessária para ajuizarem criticamente sobre o modo como o vencido de Alcácer era apresentado pelos defensores da história romântica, identificado como o mais admirável dos heróis, digno de atrair nos anais da Pátria os olhares agradecidos da Mocidade. Aliás, segundo Sérgio, o culto de D. Sebastião tornou-se obrigatório em Portugal desde que «nos dias fatais do seiscentismo» mataram o «espírito crítico» ( $\left.{ }^{\mathrm{G} 6}\right)$. Aqui reside para nós o significado essencial da polémica que opôs Sérgio a Malheiro Dias. Não se trata de uma «questão» entre historiadores que defendem pontos de vista divergentes. Daí que se nos afigure questão secundária o valor dos dados fornecidos por Sérgio aos leitores para ajuizarem do herói que Malheiro Dias propõe como modelo à Mocidade. Isso seria olhar a questão apenas com o espírito de «historiador», precisamente o que Sérgio não fez. O que se impôs foi a atitude de pedagogista que o ensaísta assumiu, visando substituir a ética romântica anti-crítica e a irracionalidade do mito sebástico, pela ética da razão, da crítica e do autodomínio que possibilitava a libertação definitiva dos espíritos.

\section{2 — «O Período Paradigmático» ou a Questão do «Seiscen- tismo $\left({ }^{87}\right)$.}

Como já tivemos ocasião de afirmar, a análise histórica é a via que, na visão integralista, permite encontrar a «ideia coordenadora» (Tradição), através da qual a Nacionalidade reingressa na sua «ideia directriz», simultaneamente monárquica e católica-romana, desviada do seu rumo pelo abastar-

$\left({ }^{65}\right)$ Idem, «História arquivística, Miragem retórica e Problemática Intelectual», ob. cit.

(C6) Idem, Tréplica a Carlos Malheiro Dias, p. 73.

(C) Esta polémica iniciou-se com a publicação do opúsculo de Manuel Múrias, O Seiscentismo em Portugal, que com algumas modificações foi apresentado como dissertação de licenciatura à Faculdade de Letras da Universidade de Lisboa. O trabalho de Múrias foi publicado na revista Lusitânia dirigida por Carolina Michaëlis de Vasconcelos, e de que era crítico literário António Sérgio.

Numa recensão crítica ao opúsculo de Múrias, no fascículo III da revista Lusitânia de Junho de 1924 , Sérgio critica as teses fundamentais do autor integralista. António Sardinha intervém e redige ${ }^{\wedge}$ um artigo intitulado «O Século XVII», publicado no fascículo I da Lusitânia de Setembro de 1924, em que corrobora as opiniões de Manuel Múrias. No mesmo fascículo, num P. S. ao artigo «Uma carta de Jaime de Ma- 
damento dos laços morais e sociais dos portugueses. Esses desvios, imputados pelos integralistas ao Renascimento, ao pombalismo e ao liberalismo do século XIX, impõem à nova geração a tarefa de reconduzirem a nacionalidade ao seu «meio natural», à semelhança do que no século XVII fizeram os homens da Restauração. O Portugal Restaurado teria resultado não de um acto político traduzido na independência imediata em relação a Castela, mas de um restauracionismo dos quadros tradicionais da velha monarquia medieval, abastardada pela influência nefasta do direito romano. Nesta linha de pensamento, a recuperação do século XVII impunha-se como tarefa urgente aos integralistas, mediante um processo de purificação da História que, segundo António Sardinha, com as suas mentiras convencionais lançara o descrédito sobre um período paradigmático da história portuguesa $\left({ }^{68}\right)$. Este descrédito que não remonta apenas à historiografia do século XIX, toda ela tecida das mentiras e dos sofismas do liberalismo, teria o seu início no período de Pombal que, rendido aos métodos da Enciclopédia, foi um «nefasto e vigoroso desnacionalizador» $\left({ }^{69}\right)$.

As acusações da Dedução Cronológica e Analítica, sintoma de uma verdadeira jesuitofobia, caíram em cheio sobre um século nascido e conformado pela Companhia de Jesus,

galhães Lima», António Sérgio anuncia a intenção de responder a António Sardinha com uma carta que se intitularia «O século XVII em Portugal, segundo o romantismo jacobiano, o romantismo reaccionário, e o humanismo imparcial e crítico». Alfredo Pimenta, no jornal a Época fez o anúncio da carta do modo seguinte: «O século XVII em Portugal, segundo o romantismo jacobiano (Teófilo Braga), o romantismo reaccionário (Manuel Múrias) e o humanismo imparcial e crítico (António Sérgio)». Entretanto morre António Sardinha, o que fez com que António Sérgio suspendesse a publicação da carta anunciada. Esta acabará por ser publicada nos números 56 e 57 da Seara Nova em 17 e 24 de Outubro de 1925, pp. 148-151 e 169-171 com o título «O problema da cultura em Portugal. O significado do Seiscentismo na sua História». Manuel Múrias reage e na revista $A$ Nação Portuguesa responde com a «Resposta à Letra» nos números 7-8 de 1925 e 9-10 de 1926, desviando a polémica da feição inicial em que se situara, ou seja, do campo da cultura, para o campo pessoal. António Sérgio responde com duas cartas nos números 87 e 88 da Seara Nova de 13 e 20 de Maio de 1926. Uma delas é dirigida aos «Jovens Seareiros de Coimbra» e a outra aos "Jovens amigos que me pedem que responda àquilo». No número 88 surge também um artigo de Carlos Miguéis «À margem do Seiscentismo. Pública explicação sob um libelo», em que defende António Sérgio.

$\left({ }^{€ 8}\right)$ Ver António Sardinha, «O Século XVII», Lusitânia, fascículo I, V. II, Setembro de 1924, p. 57.

${ }^{69}$ Idem, ibidem, p. $\mathbf{5 8}$. 
originando uma visão fălsificada do seiscentismo, visão prosseguida pela historiografia sectária do século XIX e aproveitada pela pedagogia republiçana, como razão intelectual, para a consolidação do regime. É nesse terreno que os integralistas como «bons soldados da nossa tradição católica e monárquica necessitam aceitar o combate» contra os que movidos pelo sectarismo político, aliado a preconceitos confessionais, impedem uma análise criteriosa de um dos períodos mais notáveis da história portuguesa $\left({ }^{70}\right)$.

Estes os motivos que, segundo Sardinha, levaram Manuel Múrias a escrever $O$ Seiscentismo em Portugal, através do qual procurou restituir ao séc. XVII «o sentido das suas magníficas contribuições tão adulteradas e tão pervertidas por uma crítica sectária» $\left({ }^{31}\right)$.

Múrias elogia ali rasgadamente o século XVII, século da prosa e do estabelecimento da língua portuguesa como língua de civilização, como afirma $\left({ }^{72}\right)$, opinião corroborada por António Sardinha que reconhece o seiscentismo como o século da «cultura portuguesa $\left({ }^{73}\right)$. Esta revelar-se-ia em domínios variados, desde a filosofia, à erudição, à arqueologia, à historiografia e à filologia. Esta amplidão cultural é, para aqueles autores integralistas, suficiente para impedir a manutenção da lenda de obscurantismo que envolve o século XVII e simultaneamente os jesuítas, os grandes motores dessa cultura.

Os padres da Companhia, na opinião de Múrias, foram mestres admiráveis que souberam fazer da sua «Ratio Studiorum» um método pedagógico prático e moderno, sem que se desviassem da sua preocupação dominante de conduzir as almas ao grémio da Igreja, numa perspectiva teleológica de salvação. Psicólogos argutos, revelavam já muitas das aspirações da moderna pedagogia $\left({ }^{74}\right)$.

O conhecimento correcto do esforço realizado pelos jesuítas nos domínios da cultura e da missionação constituem, portanto, para os integralistas, prova flagrante do quanto o anti-jesuitismo contaminado por Pombal e pelo Enciclopedismo falseou a interpretação do século XVII. As acusações que sobre ele pendem, de período inquisitorial e opressor, levaram Manuel Múrias a apresentar as razões justificativas do esta-

\footnotetext{
1923, p. 14.

$\left.{ }^{(T 3}\right)$ António Sardinha, «O Século XVII», ob. cit., p. 78.

$\left({ }^{\mathrm{T}}\right)$ Manuel Múrias, ob. cit., p. 33.
}

$\left({ }^{70}\right)$ Idem, ibidem.

(") Idem, ibidem.

$\left.C^{2}\right)$ Ver Manuel Múrias, $O$ Seiscentismo em Portugal, Lisboa, 
belecimento da Inquisição, da Censura prévia e dos índices Expurgatórios, que, na sua opinião, em nada afectaram o florescimento cultural da época.

Em abono desta posição, António Sardinha, afirma que o segredo desse florescimento cultural reside precisamente nos moldes e direcções impostas pela Contra-Reforma à sociedade portuguesa, o que garante o carácter tridentino que o Seiscentismo manifesta $\left({ }^{7 r}>\right.$ ). As medidas tomadas revelam-se necessárias para defender a catolicidade intrínseca do povo português, bem como para preservar a unidade nacional profundamente ameaçada pela Reforma que soprava a sua apologética e diatribes contra a Igreja católica. A este perigo acrescia o que advinha do judaísmo, «doença constitucional» que era uma ameaça séria à unidade nacional. Os judeus, na opinião de Múrias, quer pelo sectarismo religioso, quer pelo carácter onzeneiro da sua raça, nunca lograram a simpatia de nenhuma classe do reino, pelo que o Santo Ofício não foi apenas do agrado do Rei e do clero. A Inquisiçãa surge como uma fase do longo conflito que sempre dividiu cristãos e judeus.

As razões que determinaram a introdução da Companhia de Jesus e do Santo Ofício justificam, por sua vez, o estabelecimento dos índices Expurgatórios e da Censura Prévia. A Reforma, que roubava as almas da irmandade de crenças, manifestava o seu carácter dissolvente nos escritos que eram rapidamente divulgados e que pelo imprevisto e novidade empolgavam. Ora, não bastava contrapor à propaganda protestante os colégios dos jesuítas, onde se ministrava a mais rígida ortodoxia em matéria de ensino, nem tão pouco era suficiente a Inquisição. Se a leitura de qualquer livro fosse permitida, o risco de cisão religiosa permanecia. Isso explica o estabelecimento dos índices Expurgatórios e da Censura Prévia. Daí que, nenhum dos meios de que se serviu a Contra - Reforma para obstar à destruição da catolicidade do povo, fundamento da unidade nacional, tenha contribuído para a decadência do pensamento português do século XVII $\left({ }^{76}\right)$. Para o comprovar seria suficiente atentar na campanha intelectual desenvolvida em torno e a favor da Restauração.

No Seiscentismo em Portugal, Múrias dedica um capítulo ao pensamento filosófico seiscentista que, confinado na Escolástica, era ensinado nas Universidades de Coimbra e Évora. Em contraste com as novas correntes que, com Bacon

(TM) António Sardinha, ob. cit., p. 63.

$\left(^{7<5}\right)$ Manuel Múrias, ob. cit., p. 49. 
e Descartes, na Inglaterra e na França, levavam de vencida o tomismo, este desenvolve-se em Portugal, sobretudo depois que os jesuístas trouxeram para as suas escolas mestres como Suárez e Molina, cujas doutrinas, caras aos integralistas nos aspectos político e jurídico, vão servir os teóricos da Restauração, considerados por aqueles precursores das modernas correntes nacionalistas $\left({ }^{77}\right)$. António Sardinha, em apoio das posições de Múrias, e escudado no livro de Gonzague Truc, Le retour à la Scolastique, faz a apologia da filosofia escolástica que, tal como o Seiscentismo, foi vítima da «superficialidade gárrula» do século XVIII e das vitórias das «filosofias fáceis» da Enciclopédia $\left({ }^{78}\right)$.

Como os jesuítas, contra a opinião generalizada da Europa, defendiam os mesmos princípios, assim se compreende que, um século depois, o Marquês de Pombal os expulse por «monarcómacos e sequazes dos republicanos» $\left({ }^{79}\right)$. Para os integralistas, portanto, o tomismo é apresentado como uma teoria amplamente nacionalista a que os tratadistas têm que recorrer quando se lhes torne necessario defender a Restauração.

$\mathrm{Na}$ obra citada, Manuel Múrias associa ao suarismo o sebastianismo que, segundo o autor, foi falsamente interpretado como um desregramento mórbido da sensibilidade colectiva, quando deve ser visto como «magnífica floração de esperança nacionalista» que ajuda a caracterizar o génio português $\left({ }^{80}\right)$. Valorizando os temas rácicos, característica da concepção histórica integralista, Múrias considera o sebastianismo oriundo dos primeiros tempos da nacionalidade, quando a ânsia da conquista do território nacional absorvia os espíritos, mas sempre presente nas grandes acções nacionais como os Descobrimentos ou em momentos de perigos graves como em 1385, em 1640, no período das invasões francesas ou no princípio do século XIX. No século XVII, penetrando os espíritos superiores da época, como Vieira, forma com a corrente tomista um pensamento sui generis, que dá personalidade e independência à literatura de seiscentos e constitui, juntamente com as intenções da historiografia da época, o mito nacionalista que cria a certeza de que Portugal poderia libertar-se de Castela $\left({ }^{81}\right)$. Isto explica que a defesa do mito sebástico seja preocupação comum aos historiadores integra-

(") António Sardinha, ob. cit., p. 59.

(75) Idem, ibidem, p. $\mathbf{6 1 .}$

(70) Idem, ibidem, p. 68.

(80) Manuel Múrias, ob. cit., p. 55.

( $\left.{ }^{81}\right)$ Idem, ibidem, p. 93. 


\section{Antonio Sérgio}

listas, contra a opinião dos que, como Antonio Sérgio, se ocupam racionalisticamente dele.

Antonio Sardinha vê no sebastianismo a «Religião da Esperança», o «mito nacional», e concebe-o como um conjunto de forças morais e de sentimentos que excede a figura de D. Sebastião que foi o seu condensador. Para o historiador integralista, o mito sebástico não se desliga das entranhadas raízes do lirismo português, brotando da auctonia psíquica da raça. Sardinha pretende purificar o sebastianismo de toda a interpretação que via no mito um afloramento espúreo do messianismo hebraico ${ }^{82}$ ). De perfeita conformação cristã, o sebastianismo teria sido decisivo na constituição do estado de espírito que animou o Portugal Restaurado, enchendo de nacionalismo criador o caluniado século XVII. O Seiscentismo é apresentado, assim, como um período paradigmático que fornece as «lições» necessárias à solução dos problemas do presente.

Claro que esta visão em nada condiz com a interpretação que do mesmo período faz António Sérgio. Não é de estranhar, portanto, que o ensaísta, na recensão crítica que faz na Revista Lusitania à obra citada de Manuel Múrias, manifeste o seu profundo desacordo não só quanto às teses defendidas, mas também quanto à disposição intelectual que presidiu à análise histórica do autor integralista $\left.{ }^{83}\right)$. Para Sérgio, o autor do Seiscentismo em Portugal manifesta nítida falta de espírito e inteligência crítica, apresentando um conjunto de generalidades que defende com verdadeira paixão reaccionária, acabando por cair no mesmo vício dos que, com paixão jacobina, atacaram o mesmo período - o fanatismo. Assume de novo a sua preocupação de pedagogista, afirmando que o seu objectivo ao criticar as teses de Múrias é o de impedir que os jovens formem as suas opiniões em obediência a sugestões políticas, ou de outra natureza, e não através de um esforço consciente do próprio espírito $\left({ }^{84}\right)$. E esta também a preocupação que moveu o ensaísta a escrever «O Problema da Cultura em Portugal e o significado do Seiscentismo na sua História» em que se opõe às teses defendidas por António Sardinha no artigo «O Século XVII» que corrobora as posições de Manuel Múrias.

António Sérgio não aceita o messianismo de origem rá-

(82) António Sardinha, ob. cit., p. 74.

(83) Ver António Sérgio, «Recensão crítica ao Seiscentismo em Portugal de Manuel Múrias»,. Lusitânia, fascículo 3, V. I, 1924, pp. 441-8.

$\left({ }^{84}\right)$ Idem, ibidem, p. 446. 
cica, como atitude característica do povo português, nem tão pouco que o século XVII tenha sido o período de esplendor e de relevância intelectual, mercê da Companhia de Jesus, como Sardinha defende.

Para ele, o messianismo é comum a todos os povos quando são desgraçados, ou a qualquer grei que se sente incapaz $\left({ }^{85}\right)$. Se o messianismo perdura no povo português, não se pode procurar a explicação na «Raça» ou noutro qualquer atavismo, mas no facto de Portugal não ter conseguido superar a crise em que caiu. O português continua a sentir-se decadente, desgraçado, o que o leva a devanear num salvador. Só no dia em que conseguir redimir-se esquecerá a ideia de Redenção $\left({ }^{86}\right)$. Esta, a explicação simples, segundo o seareiro, para quem procura na História o «fio lógico» que permite compreendê-la, sem a complicar com os ornatos da erudição. É a simplicidade infantil do garoto do célebre conto árabe que afirma que o rei vai nú, quando todos o sopunham vestido com eruditas complicações, que Sérgio pretende trazer para o campo da História $\left({ }^{87}\right.$ ). A mesma atitude o moveu a despojar os Descobrimentos do «sonho» céltico com que os vestiram Menéndez y Pelayo e, entre nós, Teófilo Braga e Oliveira Martins. Não foi o sonho de encontrar as Ilhas Afortunadas, mas simplesmente, como diria o garoto, o comércio da índia que os portugueses, muito metódica e praticamente, trataram de ganhar. A verdade pode, portanto, ser encontrada, mesmo que contrarie celebridades, desde que o espírito actue liberto de preconceitos. Considerando-se vencedor da «questão» dos Descobrimentos com o desvanecimento do mistério da «Raça», acredita que o mesmo sucederá com o Sebastianismo, que o desastre de Alcácer serviu para aguçar e o contacto com as gentes judaicas, também messiânicas, serviu para reforçar. Rejeita a apologia que os autores integralistas fazem do século XVII, período que nos levou à situação de «índios da Europa» e transformou Portugal na «Ilha da $\mathrm{Pu}-$ rificação» $\left.{ }^{88}\right)$.

Não contesta Sérgio que existissem no reino bons comentadores da Escolástica e de S. Tomás; o que critica é o ambiente mental criado, avesso a qualquer atitude inovadora que impediu o aparecimento de vultos que, como D. João de Cas-

(85) Idem, «O Problema da Cultura em Portugal e o significado do Seiscentismo na sua História», Seara Nova, número 56 e 57, Outubro de 1925, pp. 148-151 e 169-71.

D Idem, ibidem, p. 149.

${ }^{87}$ ) Idem, ibidem.

$\left.C^{8}\right)$ Idem, ibidem, p. 150. 
tro, Garcia da Horta e Pedro Nunes, fizeram a glória da época de quinhentos.

Com efeito, em Quinhentos e Seiscentos, a Europa passou por uma revolução intelectual que culminou com a criação da atitude científica e do espírito crítico moderno e Portugal, «guarda avançada dessa alvorada», desenvolveu obra notável no livre espírito da investigação e foi pioneiro do saber experimental $\left({ }^{89}\right)$. No século XVII, esse espírito prossegue na Europa com Galileu, Pascal, Descartes e outros. Enquanto isso, Portugal caiu nas «vácuas humanidades» dos jesuitas. Só no século XVIII, com os inimigos do Seiscentismo que fugiram para a Europa, é que os primeiros tiros certeiros começaram a derrubar a prisão das palavras ocas em que o mesmo seiscentismo sepultou os portugueses $\left({ }^{90}\right)$.

Aliás, já na recensão crítica à obra de Múrias, António Sérgio tinha vincado a ideia de que o Renascimento fora o periodo em que Portugal caminhara ao lado da Europa, muito ao invés do Seiscentismo $\left({ }^{91}\right)$. $\mathrm{O}$ atraso de Portugal face ao movimento europeu não foi de inteira responsabilidade dos jesuítas, nem causado apenas pela compresssão da autoridade (através da Inquisição, Censura Prévia e Indices Expurgatórios). Para o facto, Sérgio propôs mais do que uma vez explicações de natureza económica e social que os seus opositores integralistas desconheceram $\left({ }^{92}\right)$.

Em conclusão: a defesa de um «período paradigmático» parece-nos ser o significado essencial a retirar desta polémica que opôs António Sérgio a Manuel Múrias e a António Sardinha.

\footnotetext{
( ${ }^{80}$ ) Idem, ibidem.
}

O Idem, ibidem, p. 151.

$\left({ }^{01}\right)$ Idem, «Recensão crítica ao Seiscentismo em Portugal de Manuel Múrias», ob. ext., p. 443.

(92) Idem, Breve Interpretação da História de Portugal; O Problema da Cultura, e o artigo «Em torno de um iivrinho» Seara Nova, número 201, Lisboa, 1930, pp. 140-42. Neste artigo Sérgio liga a origem da nacionalidade ao próprio nascimento da burguesia europeia que no séc. XI, em plena época feudal, inicia um tipo de economia comercial e financeira. Cria-se uma corrente de tráfico entre a Europa de Norte e o Levante de que as cruzadas são um elemento. Esta corrente, com incidência na costa Atlântica da Península Ibérica, deu esteio à independência portuguesa. Assim, Portugal afirmou desde a origem o seu carácter universalista e marítimo. $O$ grande mal foi que a activi dade marítima não foi apoiada por uma actividade produtora, que permitisse a fixação dos lucros mercantis. Os lucros iam pagar as matérias de consumo ao estrangeiro. O trabalho dos portugueses era o de transporte. Para Sérgio existe um laço lógico entre a forma da actividade económico de um povo e as suas tendências filosófico-político- 
Para os integralistas esse período é o Seiscentismo, época de puro e castiço lusitanismo em que a alma da pátria se reencontrou consigo própria. Portugal atravessara o período abastardador do Renascimento que introduziu no reino as ideias políticas do Baixo-Império romano, impedindo que a genuína filosofia política medieval portuguesa frutificasse em instituições coerentes e estáveis na organização do Estado $\left({ }^{93}\right)$. A Reforma, quebrando a unidade espiritual europeia e valendo-se da concepção patrimonial do Estado, constituía também um perigo ameaçador. O Seiscentismo reagiu contra esses movimentos. Âs concepções do Direito Romano opôs as doutrinas do suarismo e do molinismo, filiadas nas concepções tomistas medievais e que constituíam a base da filosofia político-jurídica da Restauração. Conformado aos modelos da Contra-Reforma, impediu o alastramento das ideias dissolventes da Reforma, através de meios eficazes que permitiram salvaguardar o catolicismo integralista dos portugueses, verdadeiro fundamento da unidade nacional.

Enquanto isto, António Sérgio dá-nos uma visão completamente oposta. $\mathrm{Na}$ interpretação histórico-sociológica que fez da História de Portugal, o período paradigmático correspondia à época dos Descobrimentos e Renascimento. Aí Portugal, colaborando com a Europa confirmou o seu carácter marítimo e universalista que evidenciou desde a sua origem $\left({ }^{94}\right)$. Mas tudo se modificou com os excessos do colonialismo e consequente parasitismo, e com a perseguição ao pensamento livre. Em meados do século XVI, «O Rei, a Inquisição e Jesuítas, numa fúria "purificadora» e diabólica - estalam, arrancam e arrogam aos quatro ventos a pobre árvore humanista europeia» $\left(^{95}\right)$. Portugal é reduzido à «Ilha da Purificação». Quer dizer, na linha do pensamento sergiano, admirar a época seiscentista era pretender a continuação do «grande eclipse cultural nacional», era «adorar o

-religiosas. As nações continentais têm tendência para o autoritarismo. As nações marítimas e mercantis têm tendência para a liberdade e para o não conformismo. O que convém a essas nações não é anular esse movimento com a compressão política, mas infundir-lhe ordem. Querer ser inquisidor e navegante é desejar o contraditório. No dia em que Portugal sofreu o Absolutismo e o Santo Ofício, bem como a ortodoxia do castelhano, perdeu as condições para triunfar entre os povos marítimos e comerciais.

$\left({ }^{\circ 3}\right)$ António Sardinha, Teoria das Cortes Gerais, p. 130.

(M) António Sérgio, Breve Interpretação da História de Portugal, p. 84. Ver o artigo citado, «Em torno de um livrinho».

(5) Idem, O Problema da Cultura e o Isolamento dos Povos Peninsulares. Porto, 1914, p. 25. 
maior cancro de que ainda sofria o português, era querer manter a mentalidade anti-crítica e anti-científica que fez dos portugueses «índios da Europa» $\left({ }^{96}\right)$. O remédio a dar à Grei, com conhecimento da sua doença, estaria no abandono dessa falta de senso crítico e no exorcismo dos mitos que os historiadores reaccionários arvoravam em paradigmas. Isto porque, na opinião do seareiro, só uma forte rajada de sinceridade crítica poderia edificar o "humanismo crítico» e fomentar a «reforma da mentalidade» $\left({ }^{97}\right)$, condição sine qua non para se operar o ressurgimento nacional.

\section{3 - «o Ser e o Dever Ser. Utopia regressiva e Utopia Pros- pectiva», ou a "Questão com Luís Cabral de Moncada» $\left({ }^{98}\right)$.}

O Integralismo Lusitano, ao reconhecer-se como um movimento profundamente nacionalista, coloca entre os seus antecedentes «genuinamente portugueses» as ideias contrarrevo-

(") Idem, «O Problema da Cultura em Portugal e o significado do Seiscentismo na sua História», $o b$. cit., p. 171.

(U7) Idem, ibidem.

$\left.C^{M}\right)$ Esta longa polémica, que se prolongaria por dois anos, iniciou-se com a conferência proferida pelo Professor da Faculdade de Direito da Universidade de Coimbra, Luís Cabral de Moncada, em 1 de Dezembro de 1927, na Associação Académica de Coimbra. Cabral de Moncada, se bem que não filiado no movimento integralista, perfilha as mesmas doutrinas e conviç̧ões. A conferência foi publicada com o título «Restauração do pensamento político português» no Boletim da Faculdade de Direito, da Universidade de Coimbra, V. X, Coimbra, 1929, pp. 447-77. Antes desta publicação, saiu no jornal $A V_{O Z}$ e a revista $A$ Nação Portuguesa referiu-se-lhe elogiosamente. São as seguintes as peças fundamentais da longa polémica: De Cabral de Moncada - Para além da conferência, há a assinalar, «Resposta Pronta a Vitorino Nemésio», A Nação Portuguesa, número 2, V série, Agosto de 1928 e os artigos, "Ideal e Facto Sensível, Política e Ciência, Meios e Fins», A Nação Portuguesa, número 9, V série, Março de 1929, "Método científico da História, Política (Moral) e Tradição», A Nação Portuguesa, número 11, V série, Maio de 1929 e «Idealismo e Realismo. Fim de uma polémica inútil», $A$ Nação Portuguesa, número 1, VI série, 1929. Estes artigos constituem as respostas aos artigos que António Sérgio publicou com os mesmos títulos. De Vitorino Nemésio, «Resposta Retardada - De um exortado ao exortador», Seara Nova, número 120; «Segunda Resposta Retardada», Seara Nova, número 136, Novembro de 1928. De António Sérgio, «Ideal e Facto Sensível, Política e Ciência, Meios e Fins", Seara Nova, número 144, Janeiro de 1929; «Método científico, História, Política e Tradição», Seara Nova, n. ${ }^{\text {os }} 151,153$ e 154, Março de 1929; «Idealismo e Realismo. 'Morale d'abord' e 'Politique d'abord'», Seara Nova, 163, Maio de 1929; "Ora até que enfim», Seara Nova, n. ${ }^{\circ}$ 170, Julho de 1929; «Despedida», Seara Nova, n. ${ }^{\circ}$ 174, Agosto de 1929 e «Para matar saudades», $n .^{\circ} 183$, Outubro de 1929. 
lucionárias do século XIX. Este pensamento, que assume uma feição tradicionalista, vai evidenciar um interesse enorme pela Restauração, interpretada como movimento confirmativo da tradição monárquica e católica da sociedade portuguesa. $\mathrm{O}$ Integralismo acentua esse interesse pelo momento restauracionista e pelo século em que se corporizou, «purificando-o» de acordo com os seus princípios ideológicos $\left({ }^{98}\right)$. Como já tivemos ocasião de referenciar, estes princípios vão servir, em parte, de fundamento à ideologia do Estado Novo, que, no que respeita à interpretação histórico-política, não se afasta do caminho traçado por aquele movimento.

A Restauração adquire significado importante, tomando-se um facto histórico digno de comemoração nacional. A prová-lo está a Conferência do Prof. Luís Cabral de Moncada proferida em 1 de Dezembro de 1927 na Associação Académica de Coimbra, que atesta a transferência da ideologia histórico-política do Integralismo para o Estado Novo, no qual alguns dos seus representantes irão depositar as maiores esperanças (").

Cabral de Moncada, dentro das linhas do mais puro pensamento integralista, interpreta a Restauração como uma afirmação do pensamento político português, do génio nacional, com base nas ideias e teorias políticas do Estado e da origem do poder que fundamentaram a velha monarquia medieval portuguesa. A Restauração é entendida não apenas como uma «Revolução Política», mas sobretudo como uma «Revolução de Ideias», uma «Revolução Intelectual», corporizada na independência política. O Portugal Restaurado, resultante da reestruturação da mentalidade portuguesa no domínio das ideias e das doutrinas sobre a origem e natureza do Estado, surge como que fundado pela segunda vez $\left(^{100}\right)$. A mentalidade renascente, constituída pelo conjunto das ideias que presidiram à monarquia de Afonso Henriques e que lhe serviram de fundamento e quadro lógico, tinha-se mantido até que «influências estranhas ao corpo e alma da Nação» a fizeram obliterar até aos primeiros alvores do século XVII $\left({ }^{101}\right)$ $\mathrm{O}$ direito romano, a Renascença, a Reforma e até os Descobri-

$\left.C^{a}\right)$ Ver Luís Reis Torgal, Ideologia Política e Teoria do Estado na Restauração, Vol. I, Coimbra, 1981. Ver fundamentalmente Introdução, «Interpretação da Restauração e as Ideologias Políticas», pp. 4-36.

(") Idem, ibidem, p. 33.

(100) Cabral de Moncada, «Restauração do Pensamento Político Português», ob. cit., p. 450.

(101) Idem, ibidem, p. 451. 


\section{Antonio Sérgio}

mentos, actuando como elementos desnacionalizadores, enfraqueceram as energias intelectuais, políticas e económicas do país, que, uma vez perdida a originalidade da sua concepção filosófico-política, acabou por cair nos sessenta anos do domínio castelhano $\left({ }^{102}\right)$.

Ora as ideias políticas da Contra-Reforma, iniciadas em Trento e propagadas pela Companhia de Jesus, não são outras senão as doutrinas tradicionais da Igreja católica, em que assentava a velha monarquia medieval portuguesa $\left({ }^{103}\right)$. Cultivadas pela escola teológica espanhola dos séculos XVI e XVII, tiveram em Portugal dois grandes centros: Coimbra com Suárez e Azpicuelta Navarro e Évora com Molina. Foi «ao calor destas ideias e deste renascimento que se gerou em Portugal o movimento libertador de $1640 »\left({ }^{104}\right)$. Deste modo, o patriotismo que animou os homens da Restauração tinha a encaminhá-lo um corpo de doutrinas filosófico-políticas cuja energia lhe advinha da consciência da sua primitiva constituição política que a escola teológica dos fins do século XVI acordou, doutrinas que D. João IV reconheceria nas cortes de 1641 .

Desta «lição de história» quis Cabral de Moncada tirar uma «lição moral». Seria ela a «consolação» de que Portugal, um século antes de Rousseau e século e meio antes da Revolução Francesa, dava ao mundo uma lição de liberdades públicas, de limitação do poder dos reis, quando por todo o lado triunfava já a 2 . $^{\mathrm{a}}$ edição do absolutismo. Nesse ambiente, Portugal ao proclamar que a soberania dos reis reside originariamente nos povos, estava a afirmar um pensamento político genuinamente português, fruto de uma experiência política que vinha do início da Nacionalidade, e não um pensamento estranho, filho do capricho filosófico da Razão abstracta $\left({ }^{105}\right)$. Mas, para além do «consolo», a «lição moral» a extrair deveria ser um «estímulo» para a acção política e social a era-

( $\left.{ }^{102}\right)$ Idem, ibidem, p. 463.

(103) Idem, ibidem, p. 464.

(104) Idem, ibidem, p. 465. Os princípios fundamentais da doutrina são os seguintes: Em l. $^{\circ}$ lugar a afirmação de que todo o poder vem de Deus. Essa é a origem da soberania. Mas o poder que vem de Deus é o poder abstracto porque o poder concreto, não e dado por Deus mas sim pela comunidade política ou sociedade civil. A investidura do rei é obra humana, mediante um facto a que os teólogos medievais chamavam «pactum subjectionis». Além disso, o povo ou comunidade tem sempre o direito de resistir à opressão, se o pacto for violado pelo soberano, que pode ser deposto e substituído por novo rei.

(105) Idem, ibidem, p. 472. 
preender na presente. $\mathrm{Na}$ «exortação» que dirige aos jovens, independentemente da sua ideologia republicana ou monárquica, o conferencista chama a atenção para a necessidade de Portugal ser restaurado na sua independência intelectual e espiritual, na independência do seu pensamento político e das suas tradições, da sua verdade nacional e leis fundamentais. Para isso seria necessário que Portugal se libertasse do cativeiro de um pensamento estrangeiro e anti-nacional traduzido no absolutismo democrático ou demagogia, trazido pelo liberalismo, e regressasse à filosofia política das cortes de $1641\left({ }^{106}\right)$.

$\mathrm{Na}$ «Resposta Retardada de um Exortado ao Exortador», Vitorino Nemésio, então estudante em Coimbra, sem pretender pôr em causa a «lição de história» que ouviu, insurge-se contra a «lição moral» que considera profundamente intolerante para com tudo o que é estrangeiro e um vestígio do pensamento expurgador da inquisição $\left({ }^{107}\right)$. Como republicano convicto, não aceitou a «exortação» de Moncada no sentido do regresso à ideologia política da Idade Média, a única castiçamente portuguesa, no entender do exortador.

Admitindo Nemésio a universalidade das ideias políticas, não podia, consequentemente, considerar umas nacionais e outras estrangeiras, pelo que punha em causa o carácter nacional das doutrinas defendidas por Moncada, considerando-as uma oportunística construção escolástica $\left({ }^{108}\right)$. Além de que, para o exortado, o fundamental não é o lugar de origem das ideias mas as suas «vantagens ou desvantagens intrínsecas», a sua possibilidade de realização e eficiência.

\footnotetext{
$\left({ }^{\mathbf{1 0 6}}\right)$ Idem, ibidem, p. 474.

(107) Ver Vitorino Nemésio, «Resposta Retardada - De um exortado ao exortador», Seara Nova, n. $^{\circ} 120$, Maio de 1926.

(105) Idem, ibidem. Segundo Nemésio, a doutrina da «soberania inicial» tomou corpo para bater a Reforma nas suas consequências políticas, uma vez que os teólogos protestantes, defendendo a origem directa do poder divino dos reis, furtavam à cúria romana o instrumento de influências no supremo governo dos povos, impedindo-a de distribuir coroas e ceptros. Se os teólogos peninsulares foram propulsores destas doutrinas é porque a Espanha católica procurava precaver-se contra a Europa protestante. E certo que prestou grandes serviços à Restauração, mas não se tratava então de defender a ortodoxia católica, mas sim de encontrar um fundamento teórico para a independência. Assim, para Nemésio, essas doutrinas, longe de terem sido uma concepção original e desinteressada da filosofia política portuguesa, foram uma construção escolástica essencialmente oportunística, estranha aos portugueses na sua origem estreme.
} 
Reagindo à posição de Nemésio, na «Resposta Pronta» $\left({ }^{109}\right)$ que lhe dirige, Moncada considera que o seu opositor revela falta de formação científica e positivista, e um espírito de literato mais propenso ao geral e abstracto do que à fria observação dos factos, motivo que o induziria ao erro de distinguir entre a «matéria de facto» contida na «lição de história» que proferiu, e a «matéria de fé» contida na «lição moral» que procurou extrair daquela. A fé política que manifestou não a desliga o conferencista dos factos, antes a fundamenta neles, pois constitui um conjunto de conclusões científicas a que chegou. Daí que não seja possível rejeitar a «matéria de fé», isto é, a «lição moral», sem pôr em causa a «matéria de facto», ou seja "a lição de história» $\left({ }^{110}\right)$. Quer dizer, o único critério que Moncada considera válido para comprovar as "vantagens ou desvantagens intrínsecas» das ideias e teorias políticas é o critério positivo, científico, baseado na rigorosa observação dos factos que estão para trás do momento em que se inicia a experiência de qualquer teoria.

Pensamos estar aqui o cerne da longa polémica que vai opôr Cabral de Moncada a Vitorino Nemésio e a António Sérgio. Traduz-se fundamentalmente na oposição do idealismo crítico sergiano à «política do facto» defendida por Moncada, que se prende intimamente com o problema da relação Política-Ciência, Política-Moral, Política-História (Tradição) ou, se quisermos, com o problema da relação Ser e Dever-Ser.

$\mathrm{Na}$ «Segunda Resposta Retardada» a Cabral de Moncada, Vitorino Nemésio critica a «política do facto» em que aquele se fundamenta, ao mesmo tempo que rejeita as «ideias políticas» baseadas nos factos, como «ideias científicas, insusceptíveis de erro») $\mathrm{C}^{111}$ ).

Para Nemésio, o voto, o desejo expresso, a exortação não constituem afirmações de ordem crítica, ou seja, «matéria de facto», sobretudo no âmbito da história das ideias políticas, onde o uso do método histórico permite emitir juizos de valor que, dentro de uma crítica puramente científica, não seriam possíveis $\left({ }^{112}\right)$.

Esta posição é corroborada por António Sérgio, para quem as teorias políticas exprimem ideais, fins, desejos ditados pela consciência individual, com o que a ciência posi-

(iïö) Ver Cabral de Moncada, «Resposta Pronta», A Nação Portuguesa, n. ${ }^{\circ}$ 2, V série, Agosto, 1928.

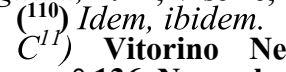
ra Nova, n. 136 , Novembro de 1926.

$\mathbf{O}^{12}$ ) Idem, ibidem. 
tiva nada tem a ver. Neste contexto, os factos não podem fundar fins ou ideais, antes são modificados por estes $\left({ }^{113}\right)$. À ciência não compete julgar ou legitimar fins. Sendo o seu domínio aquilo que é, compete-lhe interpretar esse domínio. A exortação e o ideal, pertencendo ao domínio do dever ser, não podem ser científicos nem suportados pelos factos. Consequentemente, exprimindo as políticas ideais e fins, não são de modo algum susceptíveis de demonstração científica ou de serem cientificamente refutáveis. A ciência compete apenas ensinar quais os meios mais eficazes que permitem levar aos fins desejados. Sérgio coloca-se, deste modo, numa posição completamente oposta à de Moncada que atribui à ciência um domínio que, no entender do seareiro, lhe escapa - o domínio do dever ser.

Para Sérgio, o único fundamento do ideal politico encontra-se na consciência individual, no foro íntimo de cada um, o que de modo algum se ajusta à posição positivista e realista de Moncada. O ensaísta assume uma posição espiritualista, idealista, para quem a aceitação da "política do facto» leva o seu opositor a «eliminar da política a personalidade humana» $\left({ }^{114}\right)$.

$\mathrm{Na}$ verdade, Cabral de Moncada, revelando nítidas influências positivistas, cinge a ciência à pura observação dos factos, negando no seu âmbito qualquer possibilidade à imaginação e à formação de ideias gerais e abstractas. Concebendo a política como uma ciência, exclui do seu campo os ideais (como ideais gerais), o que obriga os políticos a considerarem como lugar de experiência a própria História e a recolherem nela as «lições» que impõem o respeito pela tradição, cuja presença constante é confirmada pelos próprios factos históricos. Esta posição tradicionalista de Moncada traduz-se, para Sérgio, num anti-progressismo da própria ciência, cuja história é precisamente a luta constante contra as ideias tradicionais que impedem o seu desenvolvimento. Trata-se, segundo o seareiro, de uma confusão em que incorre Moncada ao não distinguir a Política e a Moral da Ciência. Prova disso, é precisamente a defesa que o professor de Coimbra faz da tradição, na qual reconhece, para além do valor de facto ou valor científico que Sérgio não nega, valor de direito que este contesta. Para o ensaísta, a tradição é, mas ê no domínio da ciência, da Sociologia. Aí tem valor de facto. Mas no domínio da

${ }^{(113)}$ Ver António Sérgio, «Ideal e Facto Sensível, Política e Ciência, Meios e Fins», Seara Nova, n. ${ }^{\circ}$ 144, Janeiro de 1929.

(114) Idem, ibidem. 


\section{Antonio Sérgio}

Política não lhe reconhece valor de norma, ou seja, valor de direito. Pertencendo a Tradição ao domínio do Ser e não ao domínio do Dever Ser, não pode aferir dos fins das teorias políticas. Os fins é que podem aferir da tradição, aceitando-a ou não.

O critério de escolha não depende, portanto, dos factos mas sim dos fins, dos ideais. Assim se exclui a possibilidade à história factual de ser um campo de experiência para o político, como Moncada pretendia, ou de impor o respeito pela tradição. Se o fizesse, a História estaria a contradizer-se a si própria, posto que não é a tradição que a faz, mas sim as novidades, as «quebras de tradições», as reformas radicais do existente. A tradição, ao suprimir a História, manifesta o seu carácter ahistórico ${ }^{(1 \mathrm{~B})}$ ). Quer dizer, a posição realista de Moncada é o polo oposto do idealismo de Sérgio que, colocando na consciência individual o fundamento do ideal, do fim, faz dela a mola real de toda a transformação social. Este pressuposto individualista do idealismo sergiano é rejeitado por Moncada ao filiá-lo na filosofia revolucionária do século XVIII $(116)$. A aceitação desse pressuposto, que consagra a vontade individual corno capacidade autónoma, criadora de valores morais, implica que o homem se emancipe das necessidades orgânicas criadas lentamente pela história e pela tradição, para obedecer somente aos fins formulados pela consciência e razão, fins estes que, contrapostos ao «facto sensível», se impunham como um imperativo categórico com valor absoluto. Nesta perspectiva, a Política, sobreterminada pelo reino dos fins, estaria inelutavelmente subordinada à Moral. «Morale d'abord», eis a divisa correctora do erro maurrasiano e cientifista do «Politique d'abord». Moncada rejeita esta posição porque nega à política estatuto de ciência determinadora de fins, reconhecendo-a apenas como saber determinador de meios adequados à realização dos fins propostos pela consciência. Contestando o «super-espiritualismo» sergiano que vê o homem como um «ente da razão», opõe-lhe o homem concreto, sujeito às leis do determinismo psicológico e às relações sociais impostas pela natureza e dadas pela experiência. Consequentemente, à sociedade de base individualista opõe uma sociedade concebida como um «eu colectivo» dotado de fins e leis próprias, onde o homem pode ser factor de de-

( $\left.{ }^{\mathrm{m}}\right)$ Idem, «Método científico, História, política e Tradição», Seara Nova, n. ${ }^{\text {s }} \mathbf{1 5 1}, 153$ e 154, Março de 1929.

(116) Ver Cabral de Moncada, «Ideal e Facto Sensível, Política e Ciência, Meios e Fins», A Nação Portuguesa, n. ${ }^{\circ}$ 2, V série, Agosto de 1928. 
senvolvimento, mas onde encontra limites que nem sempre consegue ultrapassar. É que, para Moncada, o «ideal» e o «facto sensível» não se anulam. Ao «facto sensível» vai a concepção política pedir explicações para aquilo que é. A Política começa por ser assim uma ciência de observação como qualquer outra. Mas é ainda no domínio do que é, do "facto sensível» que a Política encontra a «categoria do ideal». Não necessita, portanto, de sair do domínio dos factos para ir buscar as normas orientadoras a uma "consciência» abstracta e metafísica. Para Moncada, a Política, entendida como «Morale d'abord», sacrifica ao ideal o facto sensível, desdenhando dos meios e da tradição dos povos, que é o mesmo que desdenhar da Sociologia e da História. Daí que a posição sergiana se manifeste anti-tradicionalista e anti-histórica para o professor de Coimbra, que a rejeita também pelo seu carácter metafísico e místico, criador do «mito» do ideal gerado na consciência humana, o que lhe rouba o carácter científico, fazendo dela uma «metafísica, laica sem Deus e humana sem personalidade humana» $\left({ }^{117}\right)$. É, deste modo, uma posição realista, positiva, científica que Moncada opõe ao idealismo de António Sérgio. A Política funda-se no «facto sensível»e, como ciência que é, competeJhe julgar apenas o valor relativo, positivo, humano, do ideal entendido como algo realizável ou a realizar, não porque deva ser mas porque não pode deixar de ser. À política, não compete impor, em nome de critérios de valor absoluto, ideais imanentes, pois estes fundam-se nos factos; compete-lhe apenas aconselhá-los mas baseando-se na experiência desses mesmos factos. A Política não é «Morale d abord», mas «Politique d'abord» $\left({ }^{118}\right)$. Isso não significa, segundo Moncada, que a Política não seja também ciência de fins, só que esses fins, não podendo encontrar-se sem o controlo dos factos, só podem ser dados pela ciência. Sem essa base real a Política não passaria de diletantismo ou de um idealismo puro, fomentador de construções arbitrárias. Tais seriam os riscos. de uma política de matriz ética fundada na razão abstracta.

No domínio do «social» e do «político» existe uma natureza, uma certa lógica e uma certa finalidade que transcendem a lógica, a finalidade, e a natureza do individual, o que permite estabelecer a independência da Moral e da Política.

É, portanto, na perspectiva da Política como Ciência, logo distinta da Moral, que, para Moncada, a ideia de tradição é encarada como valor científico, tendo, por isso, uma

(') Idem, ibidem.

$C^{18}$ ) Idem, ibidem. 
aplicação prática, ou melhor, uma «utilização científica prática», correctora e orientadora das acções políticas concretas. Daí resulta que ela só não tem valor para os que, como Sérgio, negam à Política valor científico na formulação dos fins, ou pretendem edificar o dever ser independentemente do que é ou do que foi. É também na mesma perspectiva de uma Política científica que, segundo Moncada, se devem considerar as relações desta com a História. Tal como a Tradição, a História não é normativa; assim nada pode impor à vontade humana, pois compete-lhe apenas informar. Deste modo, se não impõe o respeito pelo dever ser da tradição, ensina que o seu constante desrespeito leva a que as construções políticas abstractas sejam inadequadas e ineficazes. Daqui se conclui que a tradição tem valor e a História tem o direito de impor às inteligểncias algumas lições $\left({ }^{119}\right)$. Esta posição de Cabral de Moncada é só por si justificativa da dupla lição, «histórica» e «moral», que quis transmitir na Conferência de 1 de Dezembro de 1927. Sem sair do campo da História, apoiado no «facto sensível», fundamentou nele o seu «ideal». Isto significa, que o «ideal», domínio do dever ser para Sérgio, está presente no domínio do ser, para Cabral de Moncada. Ele consistirá numa espécie de «utopia regressiva», ou por outras palavras, numa inserção do dever ser (ideal) no próprio ser que a História representa. Quer dizer, o projecto político de Moncada assenta no regresso à filosofia política das cortes de 1641, única genuinamente portuguesa como os factos históricos comprovam. Desse ideal político deveria constar a afirmação da soberania originária da Nação como colectividade orgânica, a alienação condicional dessa soberania nos governantes e o direito de fiscalização dos governados sobre os actos daqueles, por meio de uma representação de classes. Partindo de uma concepção orgânica da sociedade, esse projecto deveria rejeitar a noção de soberania de base individualista, do que decorreria a abolição do parlamentarismo e do regime partidário, consideradas fórmulas metafísicas da filosofia revolucionária do século XVIII $\left({ }^{12 \circ}\right)$.

Ao abandonar o campo da consciência para se situar no da História, Moncada coloca-se em clara oposição a António Sérgio, que não concebe outro fundamento para as ideias que

(110) Idem, «Método Científico, História Política (Moral) e Tradição», $A$ Nação Portuguesa, n. ${ }^{\circ} 11, \mathrm{~V}$ série, Maio de 1929.

(120) Idem, «1640.... Restauração do Pensamento Político Português», ob. cit., pp. 474-5. 
não sejam «as revelações interiores da consciência» $\left({ }^{121}\right)$. Para o seareiro, abandonar o campo da consciência pelo da História é o mesmo que abandonar a realidade pela sombra, a certeza pela dúvida, dado que o único critério seguro de certeza reside na consciência, como fonte de princípios à priori, em que toda a ciência se funda. Estes princípios intrínsecos, que por reflexão a consciência descobre em si mesma, não são conclusões científicas, mas condições da ciência $\left({ }^{122}\right)$. Isto é, Sérgio coloca na raiz da própria ciência um dever ser, traduzido na legalidade interna do eu, ou seja, na capacidade unificadora do eu racional, através de princípios formais a priori. Essa capacidade unificadora preside a toda a dialéctica do pensamento humano, seja científico, político ou moral. Daqui se conclui a existência de um paralelismo entre todas essas dialécticas, o que significa que política e moral, não se reduzindo à ciência, são filhas da unidade da consciência humana, logo são expressões dialécticas do eu racional $\left({ }^{123}\right)$. Em suma, a polémica de que nos temos vindo a ocupar polariza-se à volta do problema da relação entre a Política e a Moral, vale dizer, entre a Ciência e a Moral e os respectivos pontos de partida. Enquanto Moncada, escudado numa posição realista, o colocou no "facto sensível», no não eu, no dizer de Sérgio, este, baseado no seu idealismo, centrou-o no $e u$, ou seja, na própria actividade do espírito $\left({ }^{124}\right)$. Em consequência, o realismo de Moncada, radicando a formulação de juízos de valor, em juízos de facto, acabava por justificar, em última análise, um dado statu quo. Com efeito, alargado esse realismo ao campo social e concebendo a sociedade como um «eu colectivo» transcendente ao indivíduo, abria as portas ao conservantismo, traduzido no respeito pelas tradições. Nesta perspectiva, toda a transformação social feita em nome do que ainda não existiu aparecia como um mal a evitar e os transformadores, fonte dos males sociais, deviam ser impedidos de actuar. A esta sociedade coisificada opõe Sérgio o seu ideal de uma sociedade e de um Estado onde cada indivíduo pudesse intervir de pleno direito na vida pública.

Concebendo a sociedade como um sistema de relações pensadas entre os eus individuais, faz desse pressuposto in-

\footnotetext{
$\left.C^{21}\right)$ António Sérgio, «Realismo e Idealismo, 'Morale d'abord', 'Politique d'abord'», Seara Nova, n. ${ }^{\circ} 163$, Maio de 1929. 1090 $C^{22}$ ) Idem, «Ora até que enfim», Seara Nova, n. ${ }^{\circ} 170$, Julho$$
\left.\mathrm{C}^{1 * 23}\right) \text { Idem, ibidem. }
$$$$
\text { (124) Idem, «Para matar saudades», Seara Nova, } n .^{\circ} 183 \text {, Ou- }
$$
tubro de 1929.
} 
dividualista um ideal político, garantia da liberdade, ideal moral, comum a todos os homens. Sendo o ideal, para Sérgio, do domínio do deve ser, não podia, portanto, procurar-se no passado histórico, pois seria norma assimptótica de construção do futuro. À «utopia regressiva» que Moncada propunha, contrapunha-se uma «utopia prospectiva» fundada na consciência, ou seja, na razão entendida como capacidade autónoma e criadora. E um ideal que pretende ver concretizado numa sociedade democrática, objectivado num sistema cooperativista em que se garanta a participação de todos os indivíduos na gestão dos seus próprios destinos.

\section{Conclusão}

As três polémicas, que resumidamente expusemos e de que procurámos extrair o significado essencial, manifestam duas concepções de História, que colocámos em confronto. Se ambas evidenciam preocupações face à necessidade de um «ressurgimento nacional», os projectos político-sociais que lhes são subjacentes são completamente divergentes e traduzem duas atitudes mentais opostas.

Os integralistas, de formação positivista de direita (o Comte do Système), revelam uma atitude mental anti-racionalista, reaccionária e anti-progressista, que faz da «Tradição» o motor do seu «ideal» político. A História, cuja revisão preconizam, permite constatar a presença constante da tradição, como um facto, na alma da Nação, pese êmbora os movimentos espúreos e desnacionalizadores que por várias vezes tentaram dissolver a consciência da Grei. Como fonte de lições, ensina às novas gerações o respeito pelas «nobres superioridades» e «exorta» ao culto dos «heróis» que se impõem como modelos a seguir. Como palco de para os políticos, fundamenta os seus projectos e ideais. $\mathrm{O}$ «ideal» político, o que deve ser,presente já no ser da História, traduz-se no regresso ao próprio passado histórico, a um período paradigmático, caracterizado pelo mais puro lusitanismo.

António Sérgio assume uma posição humanista e universalista. $\mathrm{O}$ seu projecto de ressurgimento nacional, que implica uma reforma da mentalidade, visa a integração de Portugal no mundo do presente e do futuro. Para isso seria necessário ir às raizes mais fundas do "reino cadaveroso», fazer uma análise dos «vícios históricos» para exorcizar os «espectros» que, habitando a memória da Grei, impediam a formação de seres vivos. Para a prossecução deste objectivo, Sérgio combate tanto a República, cujas reformas nã̃o considerava eficazes, como o corporativismo que os integralistas já pro- 
punham e a seu ver não se coadunava com a essência racional do homem. O seu ideal político, fundado não na História mas na consciência humana, era fruto de uma concepção de um idealista, que, como alguém afirmou, pretendeu evangelizar um mundo real $\left({ }^{125}\right)$. E se esse ideal constituiu uma «utopia prospectiva», não deixou de abrir caminhos e possibilidades de reacção a movimentos petrificadores que impediam inovações e inciativas de homens livres.

Assumindo a atitude de pedagogista, procurou construir o futuro da humanidade longe do tempo dos «espectros», encarando as «navegações» do passado com o espírito de um «navegador do Mar do Futuro» $\left({ }^{126}\right)$.

$\left({ }^{1 Z 3}\right)$ Ver Vitorino de Magalhães Godinho, Ensaios $I V$, Lisboa, Sá da Costa, 1971, pp. 269-70.

(126) António Sérgio, Ensaios, t. VIII, p. 165. 